\title{
Biased Shorts: Short sellers' Disposition Effect and Limits to Arbitrage
}

von Beschwitz, Bastian and Massimo Massa

Please cite paper as:
von Beschwitz, Bastian and Massimo Massa (2015). Biased
Shorts: Short sellers' Disposition Effect and Limits to Arbitrage.
International Finance Discussion Papers 1147.
http://dx.doi.org/10.17016/IFDP.2015.1147

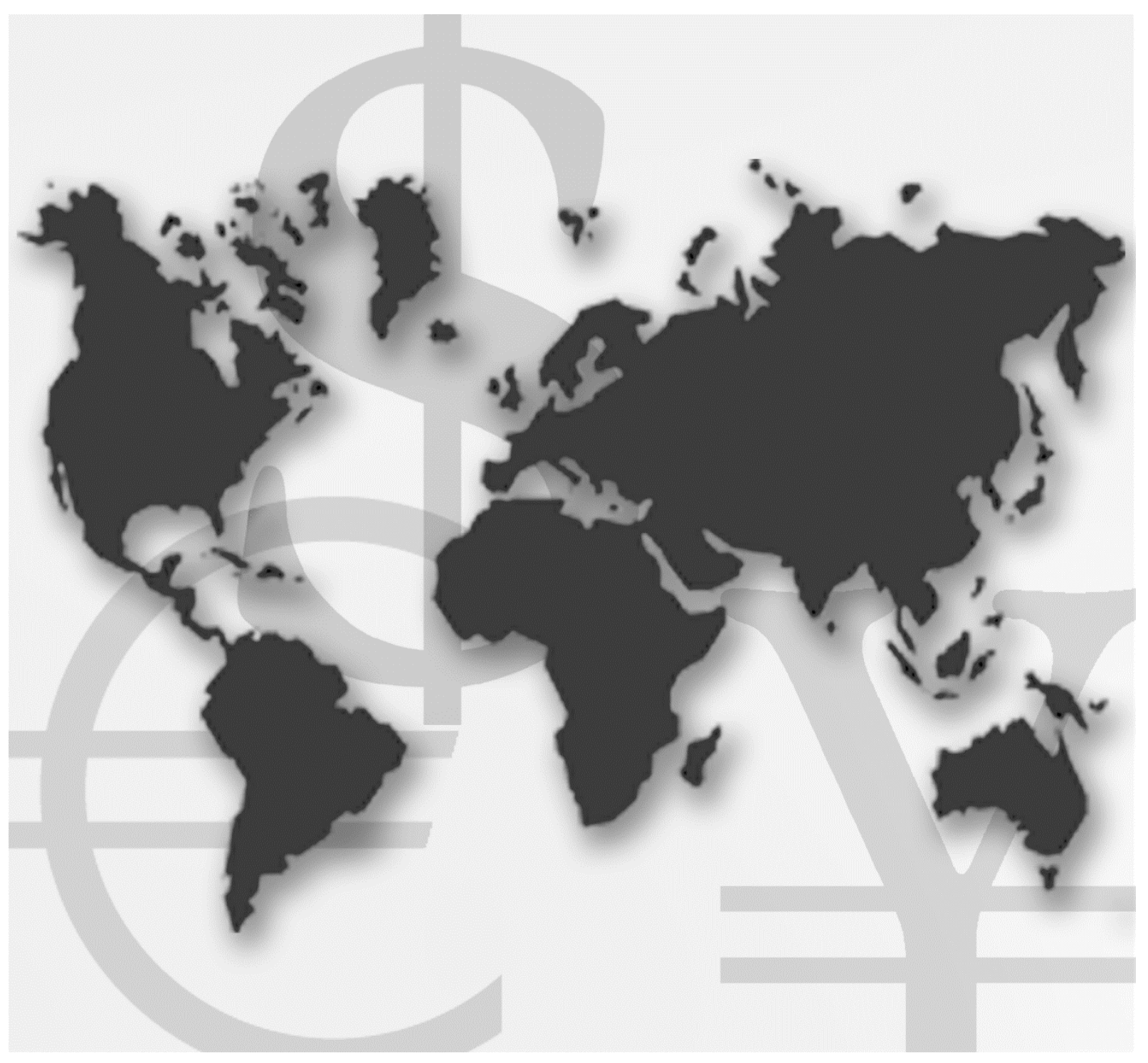

\section{International Finance Discussion Papers}

Board of Governors of the Federal Reserve System

Number 1147

September 2015 
Board of Governors of the Federal Reserve System

International Finance Discussion Papers

Number 1147

September 2015

Biased Shorts:

Short sellers' Disposition Effect and Limits to Arbitrage

\author{
Bastian von Beschwitz Massimo Massa
}

NOTE: International Finance Discussion Papers are preliminary materials circulated to stimulate discussion and critical comment. References to International Finance Discussion Papers (other than an acknowledgment that the writer has had access to unpublished material) should be cleared with the author or authors. Recent IFDPs are available on the Web at www.federalreserve.gov/pubs/ifdp/. This paper can be downloaded without charge from the Social Science Research Network electronic library at www.ssrn.com. 


\title{
Biased Shorts: \\ Short sellers' Disposition Effect and Limits to Arbitrage
}

\author{
Bastian von Beschwitz Massimo Massa *
}

\begin{abstract}
We investigate whether short sellers are subject to the disposition effect using a novel dataset that allows to identify the closing of short positions. Consistent with the disposition effect, short sellers are more likely to close a position the higher their capital gains. Furthermore, stocks with high short sale capital gains experience negative returns, suggesting that their disposition effect has an effect on stock prices. A trading strategy based on this finding achieves significant three-factor alphas. Overall, short sellers' behavioral biases limit their ability to arbitrage away the mispricing caused by the disposition effect of other market participants.
\end{abstract}

Keywords: Short selling, Disposition effect, Behavioral finance

JEL classifications: G10, G12, G14

\footnotetext{
* Bastian von Beschwitz, Federal Reserve Board, International Finance Division, 20th Street and Constitution Avenue N.W., Washington, D.C. 20551, tel. +1 202475 6330, e-mail: bastian.vonbeschwitz@gmail.com (corresponding author).

Massimo Massa, INSEAD, Finance Department, Bd de Constance, 77305 Fontainebleau Cedex, France, tel. + 33(0)160-724-481, email: massimo.massa@insead.edu We thank the UniCredit \& Universities Knight of Labor Ugo Foscolo Foundation for a research grant that made this study possible. We thank Itzhak Ben-David, Bing Han, Matthew Ringgenberg, Anna Scherbina, Noah Stoffman and seminar participants at WFA, EFA, SFS Cavalcade, INSEAD, the Whitebox Advisors Graduate Student Conference and the German Economists Abroad Christmas Conference for helpful comments.

The views in this paper are solely the responsibility of the author(s) and should not be interpreted as reflecting the views of the Board of Governors of the Federal Reserve System or of any other person associated with the Federal Reserve System.
} 


\section{Introduction}

The finance literature has devoted considerable attention to the effects of behavioral biases on the stock market. However, the vast majority of this research focuses either on individual household investors who are neither qualified nor informed enough to trade profitably (e.g., Odean (1998), Odean (1999), Barber and Odean (2000), Huberman (2001), Genesove and Mayer (2001)) or on mutual fund managers (Coval and Moskowitz (1999), Frazzini (2006), Jin and Scherbina (2011)), in general assumed to be uninformed. It is less known whether financial professionals possessing both sophistication and information also succumb to psychological biases. The evidence on financial professionals is extremely limited and mixed. Coval and Shumway (2005) document that future traders trading for their own account display behavioral biases. In contrast, Locke and Mann (2005) show that futures traders are able to discipline themselves and escape the negative performance implications of behavioral biases. In both cases, the focus is on financial professionals but it is not clear whether they are necessarily better informed.

Instead, the goal of this study is to investigate the existence and market impact of behavioral biases among investors believed to be rational, sophisticated, and well informed. We explore this subject by focusing on short sellers. Several studies show that the amount of short selling predicts future stock returns (Boehmer, Jones and Zhang (2008), Engelberg, Reed and Ringgenberg (2012), Cohen, Diether and Malloy (2007), Diether, Lee and Werner (2009), Boehmer, Huszar and Jordan, (2010)) implying that short sellers are informed. Indeed, most short selling is undertaken by sophisticated traders such as hedge funds, which are structurally 
very different from the traditional focus group of behavioral finance - i.e., unsophisticated and/or less informed traders.

More importantly, the fact that short sellers can scale up their trades to a very high multiple of their underlying capital and that they are thought of as arbitraging away mispricing, suggests that behavioral constraints on their actions have direct implications for the stock market, effectively increasing the "limits to arbitrage". This implies that any evidence of behavioral biases among these traders should have more relevant equilibrium, practical and normative implications than the previous evidence on retail investors, long-only managers or even professional futures traders.

While short selling has been extensively researched in the finance literature, it has never been studied in the behavioral context. Rather, short sellers are perceived as rational speculators and the debate has centered on whether they are detrimental or beneficial to the overall investment community, or whether regulatory short sale constraints have a tangible effect on stock prices. In contrast, we investigate whether the trades of short sellers are indicative of a behavioral influence and what are the effects of "irrational" short selling activity on the stock market.

We focus on the disposition effect - i.e. the tendency of traders to hold on to their losing stocks too long while selling their winning stocks too early (Shefrin and Statman (1985)). This behavioral bias is "one of the most robust facts about the trading of individual investors" (Barberis and Xiong (2009)). If traders are subject to the disposition effect, they should have higher demand for losing stocks than for winning stocks. Therefore, our first hypothesis is that short sellers react to previous accumulated losses/gains by holding on to the stocks in which 
they lose - i.e., the stocks that have experienced a cumulated increase in price - and selling the stocks in which they gain - i.e., the stocks that have experienced a cumulated decrease in price.

Our second hypothesis is that this behavior has equilibrium implications. To understand these implications, we apply the model of Grinblatt and Han (2005) to short sellers. In their model, a subset of traders is subject to demand distortions driven by the disposition effect i.e., they have lower demand for stocks with capital gains and higher demand for stocks with capital losses. Due to market frictions/inelastic demand, these demand distortions distort market prices away from the fundamental value which would prevail if all traders were rational. This will make stocks with capital gains undervalued and stocks with capital losses overvalued. The undervaluation (overvaluation) will be bigger the higher the aggregate capital gains (losses) are. As prices are pushed back to fundamental value by rational traders over time, expected future returns will be higher, the more positive the aggregate capital gains.

We build on this model and customize the intuition for the case of short-sellers exhibiting the disposition effect. Under the assumptions of Grinblatt and Han (2005), if short sellers' propensity to short a stock is negatively related to their capital gains, then stocks with short sale capital gains are overvalued while stocks with short sale capital losses are undervalued. Because stock prices move back to their fundamental value over time, short sale capital gains (losses) predict negative (positive) future returns. Thus our second hypothesis is that short sale capital gains are negatively related to future returns.

Grinblatt and Han (2005) argue that the disposition effect can explain stock price momentum. Indeed, because higher past returns lead to higher capital gains, the prediction that capital gains and expected future returns are positively correlated implies stock price 
momentum. We argue that due to a "double negative" the same is true for short sellers. Their capital gains are negatively related to past returns, but also predict future returns negatively. Therefore, disposition effect behavior by short sellers will also contribute to stock price momentum. Put differently, the disposition effect will always cause traders to underreact to news (because disposition effect behavior makes a trader more contrarian), irrespective of whether the trader is a long trader or a short seller.

If short sellers' disposition effect also leads to momentum, this will reduce their ability to arbitrage away mispricing coming from the disposition effect of long traders. While short sellers are usually thought of as arbitrageurs that reduce mispricing in the market and short sale constraints are often cited as a limit to arbitrage (e.g. Miller (1977)), these considerations suggest that behavioral biases of short sellers constitutes "limits to arbitrage".

We test our two hypotheses by focusing on weekly short selling behavior over the period from August 2004 to June 2010 on all US stocks. We use a dataset on equity lending provided by Data Explorers (now Markit). This dataset has already been used by Saffi and Sigurdsson (2011) and Engelberg, Reed and Ringgenberg (2014) and has become the main source of information on short selling. However, we are the first to use it to back out the closing of short positions, which is crucial information when testing for the presence of the disposition effect.

We start by investigating whether short sellers are more likely to close positions with higher capital gains, as is predicted by the disposition effect. We therefore define a measure of Short sale Capital Gains Overhang (SCGO) as the average percentage gains of short sellers relative to the price at which they entered their positions. While we do not have individual trading records of short sellers, we can estimate the average price at which positions were 
entered from aggregate trading behavior by adopting a methodology used in Grinblatt and Han (2005). We find a strong positive and statistically significant link between the closing of short positions and SCGO. A one standard deviation increase in SCGO increases the share of open positions that are closed by 0.6 percentage points, which is $5 \%$ relative to the unconditional median. If we compare this finding to the results reported in Odean (1998), we find that the average retail investor in Odean's data exhibits a disposition effect that is approximately 6 times as strong as that of the average short seller.

An event-based analysis further supports the hypothesis that short sellers condition their closing on capital gains because of the disposition effect rather than for some rational motivation. First, we expect algorithmic traders not to be affected by behavioral biases and therefore, an event that exogenously reduces the number of algorithmic traders should provide an ideal experiment. We focus on the 2009 momentum crash, a period in which the popular momentum strategy had strongly negative returns. After the momentum crash, many algorithmic traders went out of business (Daniel and Moskowitz (2013)), which increased the percentage of short sales undertaken by human traders. In line with our working hypothesis, we find that the positive relationship between SCGO and the closing of short positions increases after the momentum crash, when a larger fraction of short sales are done by human traders.

Second, we expect the closing of short positions in long-short strategies not to depend on SCGO, because long-short traders most likely estimate their gains and losses over the combined long-short position. We therefore focus on M\&As. During these events, most of short-selling is done as part of a long-short strategy betting on the convergence (or divergence) 
of the target's and bidder's stock prices. Therefore, we expect the disposition effect on just the short selling position not to play a significant role. And indeed, we find that the positive relationship between SCGO and the closing of short positions decreases during the time of a merger when a large part of short selling activity is done to engage in the long-short strategy of merger arbitrage.

Third, we expect short sellers to give in less to the disposition effect when it is more costly to hold on to stocks for too long. In line with this idea, we find that the relationship between the closing of short positions and SCGO is attenuated for stocks that are expensive/difficult to borrow - i.e., small, illiquid stocks, stocks with low institutional ownership or stocks with a high lending fee. This result not only supports our working hypothesis, but it also implies that our results are driven by large and liquid stocks - i.e., the ones in which it is cheap to hold a position open (too) long. This makes it unlikely that our results are driven by forced closure of short positions.

Next, we focus on the implications for stock prices. Consistent with our second hypothesis and the theoretical model of Grinblatt and Han (2005), we find that SCGO is negatively related to future stock returns. In particular, a one standard deviation increase in SCGO decreases future returns by 8 basis points per week or $4.2 \%$ per year. This finding is consistent with an equilibrium stock price impact of short seller’s disposition effect.

A potential concern is that short sellers hold on to their losing positions for rational reasons, because they know that these losses will eventually turn into gains. Finding support for both our hypotheses indicates that this is not the case and that we observe a behavioral bias. Indeed, taken together, our results show that high SCGO are followed by more closing of positions as 
well as more negative stock returns. This means that short sellers are closing more positions exactly at the time when it would be profitable to keep the short position open and profit from the negative future return. Thus, their tendency to hold on to their losing positions and close their winning ones causes them to lose money, a clear sign that it is not a profit maximizing strategy.

Next, given that Grinblatt and Han (2005) document a positive correlation between long traders' capital gains and stock prices, we assess whether our results are genuine or whether SCGO just spuriously proxy for the capital gains of long investors. We therefore regress stock returns on SCGO as well as a proxy of capital gains of long traders (Long Capital Gains Overhang (LCGO)). We find that both types of capital gains affect future returns. One standard deviation increase of SCGO decreases the return by 5 basis points per week or $2.8 \%$ per year, when controlling for LCGO. At the same time, one standard deviation increase in LCGO increases the return by 13 basis points per week or 7\% per year, when controlling for SCGO. Given that positive stock returns will lead to an increase in LCGO, but to a decrease in SCGO, these results imply that disposition effect behavior leads both long traders and short sellers to add to momentum. This suggests that behavioral biases do indeed reduce the ability of short sellers to arbitrage away mispricing, thereby effectively acting as limits to arbitrage.

Finally, we examine whether the relationship between SCGO and future returns can be used to implement a profitable trading strategy. To do this, we study portfolios based on SCGO. In addition to SCGO, we sort stocks by past returns to control for momentum. We form 16 portfolios by double-sorting stocks on the basis of SCGO and past returns. A trading strategy that goes long in the lowest SCGO quartile and short in the highest SCGO quartile earns a 3 
factor alpha of 8 to 30 basis points a week or $4.4 \%$ to 17\% a year. Except for the quartile with the most negative past returns, this return is significant at the $5 \%$ threshold. If we follow Grinblat and Han (2005) and exclude January in which trades might be influenced by tax considerations and in which we generally do not observe a momentum anomaly (e.g., Jegadeesh and Titman (1993)), the alpha increases even more to $12 \mathrm{bp}$ to $47 \mathrm{bp}$ per week or $6.4 \%$ to $27 \%$ per year. This performance is fairly consistent over our sample period (see Figure 1 and 2).

These results support our second hypothesis and indicate how the behavioral bias directly impacts stock prices by limiting the ability of short sellers to arbitrage. Furthermore, they confirm that short sellers are losing money by basing their trades on their capital gains. This shows that short sellers are indeed subject to a behavioral bias and do not just hold on to profitable positions that they established due to private information.

Overall, our findings document that short sellers are subject to the disposition effect and show a direct impact of such a bias on stock prices. This analysis has important normative implications. Indeed, there is a big debate on whether short sellers are beneficial or detrimental to the market and whether regulatory short sale constraints have a tangible effect on stock prices. However, if short sellers themselves are irrational, then the classic view of short selling as an arbitrage device is dubious. Our results help explain why certain market anomalies persist despite the apparent availability of arbitrage capital. The fact that behavioral biases reduce the ability of short sellers to react, while negative in general, during a crisis, may in fact help to slow down market reaction, potentially smoothing it. This would reduce the need to curb short selling activity as the very behavioral bias acts like a self-regulatory device for short sellers. 
Our findings contribute to several strands of literature. First, we contribute to the literature on short sellers' behavior. Short sellers have been traditionally identified as rational traders either endowed with superior private information (e.g., Cohen, Diether and Malloy (2007)), or better able to process public information (e.g., Engelberg, Reed and Ringgenberg (2012)). We contribute to this literature by showing the behavioral and irrational side of short selling behavior.

Second, we contribute to the literature on the impact of short sellers' behavior on stock prices. Several studies make a connection between short sellers' activity and stock returns (Senchack and Starks (1993), Asquith and Meulbroek (1995), Aitken et al. (1998)). It has been shown that the impact takes the form of improving liquidity and market efficiency (Bris, Goetzmann and Zhu (2007), Boehmer, Jones and Zhang (2008), Boehmer and Wu (2013), Saffi and Sigurdsson (2011)). Alternatively, their impact has been linked to numerous constraints to which short sellers are subject (Miller (1977), Jones and Lamont (2002), Diether, Malloy and Scherbina (2002)). In both cases, stock characteristics are linked to rational short selling behavior. In contrast, we link mispricing to the unconstrained but suboptimal decisions undertaken by the apparently rational and sophisticated traders. The prevalence of the disposition effect among short sellers can explain why stock returns exhibit momentum and why this anomaly can persist.

Third, we contribute to the literature on behavioral biases and, in particular, on the disposition effect. This literature is both empirical/experimental (e.g., Weber and Camerer (1998), Odean (1998), Locke and Mann (2005), Heath, Huddart and Lang (1999), Grinblatt and Keloharju (2000, 2001), Grinblatt and Han (2005), Ben-David and Hirshleifer (2012)) and 
theoretical (Gomes (2005), Berkelaar and Kouwenberg (2000), Barberis and Huang (2001), Barberis, Huang and Santos (2001), Ang, Berkaert, and Liu, (2001)). We contribute to it by providing evidence that supposedly rational and well informed traders such as the short sellers are also prone to the disposition effect.

The remainder of the paper is organized as follows. Section 2 lays out the main hypotheses. Section 3, describes the sample and the main variables of interest. Section 4 and 5 show our empirical results. A brief conclusion follows.

\section{Main Hypotheses}

Much of the economic and financial theory is based on the notion that individuals act rationally and consider all available information in their decision-making process. However, previous research has uncovered substantial evidence that contradicts this assumption and documented repeated errors in judgment by investors. We focus on one bias: the disposition effect and study whether it affects short sellers, a group of traders usually considered to be informed and sophisticated.

The disposition effect is the irrational tendency to hold on to losing positions too long and to close winning positions too early (e.g., Shefrin and Statman (1985)). Therefore, this bias induces traders to condition their closing of short positions on their capital gains. Specifically, they are more likely to close a position, the higher the capital gains (and more likely to hold on to the position the higher the capital loss). This allows us to posit our first hypothesis.

H1: Short sellers' closing of short positions is positively correlated with the amount of capital gains. 
What are the equilibrium implications? To answer this question, we follow Grinblatt and Han (2005). They provide a theoretical model in which a subset of traders is subject to the disposition effect - i.e., they have lower demand for stocks they hold with capital gains and higher demand for stocks they hold with capital losses. Grinblatt and Han (2005) assume that the demand for the stock by rational investors is not perfectly elastic, which allows the disposition-prone traders to distort prices away from the fundamental value that would prevail if all traders were rational. Their model studies the size of the distortion in equilibrium prices and returns relative to the benchmark where all traders are rational. In their model, due to the disposition effect prone traders, stocks that are held with positive aggregate capital gains are undervalued, while the opposite is true for stocks with negative capital gains.

The fact that some traders are not affected by the disposition effect will make prices move back to fundamentals in the long run and implies that price distortions lead to return predictability. Thus, stocks with aggregate (unrealized) capital gains outperform stocks with aggregate (unrealized) capital losses. Given that stocks with positive past returns are more likely to be held at positive capital gains, the model implies underreaction to news and subsequent momentum. For example, a positive news event will lead to positive capital gains. The traders holding stocks at a capital gain are more likely to sell. This "excess selling pressure” limits the stock price increase to the positive news and pushes the stock price below its fundamental value. As prices revert to their fundamental value over time, positive capital gains are followed by positive returns. The mirror image is true for negative capital gains.

We apply the model of Grinblatt and Han (2005) to short sellers. If short sellers’ propensity to short a stock is negatively related to their capital gains, then stocks with short sale capital 
gains are overvalued while stocks with short sale capital losses are undervalued. Because stock prices move to their fundamental value over time, short sale capital gains (losses) predict negative (positive) future returns. Therefore we propose:

H2: Short sale capital gains overhang predicts stock returns. Short sale capital gains (losses) predict future negative (positive) returns.

This hypothesis implies that the disposition effect of short sellers also leads to momentum due to the following "double negative”: Short sellers lose money when stock returns are positive, but when they close a position they need to buy rather than sell the stock. In the presence of positive short sale capital gains (following negative returns), short sellers are more likely to close - i.e. buy back the stock - and thus inflate the price. As the price revert to fair value over time, negative returns are followed by more negative returns and we observe momentum in stock prices. Another way to say this, is that disposition effect will cause underreaction to news and thus subsequent momentum independent of whether the trader is a short seller or a long trader.

It is important to note that $\mathrm{H} 2$ also implies that the tendency to close winning positions and hold on to losing positions is behavioral. Indeed, finding only support of $\mathrm{H} 1$ is not sufficient to show that short sellers are subject to a behavioral bias, because $\mathrm{H} 1$ is also consistent with the following explanation: Short sellers enter a short position if they have private information that the stock is overvalued. If prices move higher and short sellers make a capital loss, they might hold on to their position, because the stock is now even more overvalued. Similarly, short sellers might close their positions after share price decreases because the share price has fallen below the short sellers' private valuations. We can distinguish disposition effect behaviour 
from this rational explanation by examining whether short sellers make higher profits by holding on to their losing positions and closing their winning positions. If the tendency is behavioural, we expect short sellers to lose money by conditioning their trades on their capital gains, while we could expect them to gain money if they do so for rational reasons.

Finding support for $\mathrm{H} 2$ implies that short sellers are losing money by acting as predicted in H1. The logic is as follows: If high short sale capital gains are followed by more closing of short positions (H1) and by negative returns (H2), then short sellers close their positions before a stock further loses value - i.e., they forego profits. Similarly, if they hold on to positions in which they have high capital losses (H1) and high capital losses are followed by positive returns (H2), they also lose money. Thus, evidence in favor of H1 and H2 confirms that short sellers are losing money and thus are subject to a behavioral bias as opposed to a rational informationdriven - and therefore profitable - behavior.

Before moving on to the main results, we describe the data we use and the main variables.

\section{The Data and the Main Variables}

We employ equity lending data provided by Data Explorers (now Markit) as well as the standard datasets on stock returns (CRSP), balance sheet data (Compustat), analyst coverage (I/B/E/S), and institutional ownership (Thompson Reuters 13f filings).

\subsection{Short selling data}

We obtain equity lending data from Data Explorers, a privately owned company that supplies financial benchmarking information to the securities lending industry and short-side intelligence to the investment management community. Data Explorers collects data from custodians and prime brokers that lend and borrow securities and is the leading provider of 
securities lending data. For each stock, Data Explorers reports the following variables at daily frequency: lendable value in dollars, active lendable value in dollars, total balance value on loan in dollars, and weighted average loan fee (across active contracts) in basis points.

We limit our attention to U.S. common stocks (share codes of 10 or 11 in CRSP). In addition, we exclude all companies with a market capitalization of less than 10 million or a share price of less than 1 USD. The data span the period from August 2004 to June 2010. Until July 2006, the data are only available at a weekly frequency, while from then on, data are available at a daily frequency. Since all of our analyses are made at the weekly frequency, we will use the full sample from 2004 to 2010 . We exclude from all our analyses any week that included the time period of the short selling ban following the financial crisis - i.e., we exclude September 15, 2008 to October 10, 2008.

In the United States, equity transactions are settled after three trading days, while equity loans are settled immediately. Accordingly, a short seller does not need to borrow a stock until 3 days after taking his or her short position. Therefore, we make the standard adjustment to compute the amount of shorted stocks on a day using the shares on loan at $t+3$ following Geczy, Musto and Reed (2002), Thornock (2013).

The Data Explorers dataset has the unique feature that it contains information on the number of shares that are on loan as well as the number of shares that have been newly lent out during the last week. This allows us to compute the number of shares that have been returned to lenders during the day as follows: ${ }^{1}$

\footnotetext{
${ }^{1}$ More detailed information on variable construction is provided in Appendix 1.
} 
Shares Returned $d_{t}=$ Shares newly borrowed b $_{t}$ Shares on loan l $_{t}+$ Shares on loan $_{t-1}$ Having access to information on the closing of the positions is very important for this study, as the disposition effect affects the closing of positions. Our main variable of interest is Closing, which is defined as the percentage of shares at the beginning of the week that were returned to lenders during the week:

$$
\text { Closing }_{t}=\frac{\text { Shares Returned }}{t} \text { Shares on } \text { loan }_{t-1} .
$$

This variable captures the percentage of positions that are closed, thereby being our analog to the Percentage of Gains Realized (PGR) and Percentage of Losses Realized (PLR) employed in Odean (1998) and Frazzini (2006). As control variables, we use among others, the average fee (value-weighted) that short sellers have to pay to borrow the stock and the average number of days (value-weighted) that they hold the short position open.

\subsection{Constructing capital gains variables}

The disposition effect is the irrational tendency of traders to sell stocks with high capital gains and to hold on to stocks with low capital gains. Capital gains are defined relative to the trader's reference point - i.e., the price at which traders entered their position (e.g., Thaler (1980), Shefrin and Statman (1985), Odean (1998), Frazzini (2006)). In our context, this corresponds to the price at which the short sellers have sold the stock short. Since we do not have access to individual short sellers' portfolios, we have to estimate the average price at which the short sellers entered their current position. To do this, we follow the methodology of Grinblatt and Han (2005). We apply it to short sellers weekly trading. More specifically, we estimate: 


$$
R_{t}=R_{t-1} *\left(1-\frac{\text { Shares Newly Shorted }_{t}}{\text { Shares on } \text { loan }_{t}}\right)+\frac{\text { Shares Newly Shorted }_{t}}{\text { Shares on loan }} * P_{t} \text {, }
$$

where $R_{t}$ is the reference price and $P_{t}$ is the market price. ${ }^{2}$ This recursive method computes the new reference price as a weighted average between last week's reference price and today's price. The weight on today's price equals the percentage of total open short positions that were entered in the last week. Basically, this approach assumes that all short positions have the same probability of being closed independent of when they were opened.

As an alternative measure, we construct the reference price using information from Data Explorers on how long a stock has been lent out. We only have relatively coarse information. We know the percentage of shares lent out 1 day ago, in the last 3 days, in the last 7 days, in the last 30 days and longer than 30 days ago. We use this information to estimate the reference price as follows:

$$
\begin{array}{rl}
R_{\tau}^{\text {alt. }}=S_{\tau-1} & * P_{\tau-1}+S_{\tau-3, \tau-2} * P_{\tau-2}+S_{\tau-7, \tau-4} * P_{\tau-4}+S_{\tau-30, \tau-8} * P_{\tau-8}+S_{\tau-\infty, \tau-31} \\
& * P_{\tau-31}
\end{array}
$$

where $R_{\tau}{ }^{a l t}$.is the alternative definition of the reference price at date $\tau^{3}, P_{\tau}$ is the price at date $\tau$ and $S_{\tau, s}$ is the share of stocks that were shorted between dates $\tau$ and s. For each window of short selling horizon, we use the prices closest to the current market price. This leads to an underestimation of the difference between the current price and the reference price, but should not introduce any bias.

\footnotetext{
${ }^{2}$ Both market price and reference price include dividend payments, i.e. they are computed from total returns.

${ }^{3}$ We use $\tau$ to illustrate the daily frequency, while t refers to the weekly frequency.
} 
Because short sellers profit when the stock price decreases, we compute the capital gains overhang of the short seller for both our reference prices as:

$$
S C G O_{t}=\frac{R_{t}-P_{t}}{R_{t}}
$$

We define Short Sale Capital Gains Overhang I (SCGO I) as the capital gains overhang constructed using the reference price of the recursive methodology $\left(R_{t}\right)$ and define Short Sale Capital Gains Overhang II (SCGO II) as the capital gains overhang constructed using the reference price computed from short seller horizon $\left(R_{\tau}{ }^{a l t}\right.$. $)$. Both variables are an estimate of the average capital gains with which short sellers hold the specific stock. They generally increase as stock prices fall and decrease as stock prices appreciate.

As a comparison, we also estimate the capital gains of long traders in the market. Following Grinblatt and Han (2005), we compute the reference price of long traders at a weekly frequency recursively as:

$$
R_{t}=R_{t-1} *\left(1-\frac{{\text { Shares } \text { Traded }_{t}}_{\text {Shares Outstanding }}}{\text { Shares Outstanding }_{t}} * P_{t}\right.
$$

Then, we compute the capital gains of long traders as:

$$
L C G O_{t}=\frac{P_{t}-R_{t}}{R_{t}}
$$

Long Capital Gains Overhang (LCGO) is an estimate of the average capital gains with which long traders hold the specific stock. It is the same variable as constructed in Grinblatt and Han (2005). It generally decreases as stock prices fall and increases as stock prices appreciate. 
Following Grinblatt and Han (2005), we run all our tests at the weekly frequency. The use of the weekly frequency is a good balance between a high enough frequency that allows us to have an accurate estimation of computed capital gains and a low enough frequency that reduces the influence of market microstructure effects. Also it allows us to use the longer time period from August 2004 to June 2010 in our short selling data.

\subsection{Control variables}

For each of the firms covered in the short selling data, we retrieve stock market data from CRSP and balance sheet data from Compustat to compute market capitalization and book-tomarket ratios. In addition, we use the $\mathrm{I} / \mathrm{B} / \mathrm{E} / \mathrm{S}$ database to construct measures of analyst following. We define Number of Analysts as the logarithm of one plus the number of analysts that issued earnings forecasts for the stock in the observation period. We obtain data on institutional ownership from Thompson Reuters 13f filings. Institutional Ownership is computed as the aggregate number of shares held by institutional investors divided by the total number of shares outstanding. Breadth of Ownership is defined as the number of institutions holding the stock divided by the number of all reporting institutions in the period (similar to the definition used by Chen, Hong and Stein (2002). Amihud Illiquity is defined as: Amihud Illiqudity $=$ mean $_{\text {over quarter }}\left(\frac{\mid \text { ret }_{\text {daily }} \mid}{\text { dollar volume }_{\text {daily }}}\right)$. Given that this measure often has large outliers, we use 100 percentiles rather than the continuous variable. Companies with the highest Amihud illiquidity are assigned a value of 100, companies with the lowest Amihud Illiquidity are assigned a value of 1 . To reduce the effect of outliers, all variables are winsorized at the 1\% cut-off. All variable definitions can also be found in Appendix 1. 


\subsection{Summary Statistics}

We report summary statistics in Table 1 . In our sample, we have stocks of 6,134 U.S. companies and roughly 1 million company-week observations. In Panel A, we report the average of company variables over company-year observations. The mean market capitalization is 2.5 billion USD (median 350 million USD). The mean market to book ratio is 2.78 (median 1.94). The companies are covered on average by 5 analysts (median 3), but more than $25 \%$ of the sample firms have no analyst coverage. Institutional ownership is on average $50.7 \%$ (median 52.8\%).

In Panel B, we report summary statistics of the market variables. On average 3.9\% (median $1.7 \%)$ of shares outstanding are on loan. Every week, on average (median) $0.57 \%(0.24 \%)$ of the shares outstanding are newly borrowed (i.e., newly shorted) and on average (median) 19\% (13\%) of the shares on loan are returned to lenders (closed short positions). The median of Average Lending Fee is 14 basis points, so most stocks are very cheap to short sale. The average Short Sale Duration is 77 days (median 62). The mean turnover is $4.2 \%$ per week (median 2.5\%). This implies that the average long trader has a longer investment horizon of 24-40 weeks. The average weekly return is $0.2 \%$ (median $0 \%$ ). The average Short Sale Capital Gains Overhang I (SCGO I) is slightly positive with $0.9 \%$ (median $0 \%$ ), while the alternative specification (SCGO II) is on average slightly negative with $-0.1 \%$ (median $-0.3 \%$ ). Long Capital Gains Overhang (LCGO) is positive on average with 1\% (median 1.8\%), probably due to the positive average return. The higher standard deviation of LCGO compared to SCGO (28\% compared to $11 \%$ ) is most likely due to the longer investment horizon of long traders. Since long traders hold on to stocks longer, they can accumulate more extreme levels of capital 
gains overhang. The standard deviation of LCGO is very close to the value reported in the study of Grinblatt and Han (2005) (27.6\% compared to 25.1\%).

\section{Do Short Sellers Exhibit the Disposition Effect?}

In this and the following section, we present the empirical results of our paper. In this section, we examine Hypothesis 1 that short sellers are more likely to close positions with positive capital gains. In section 5, we focus on Hypothesis 2 that short sell capital gains are followed by negative returns. This will allow us to confirm that this behavior is indeed a behavioral bias and will enable us to examine how this bias affects stock market characteristics in equilibrium.

\subsection{Evidence of short sellers' disposition effect}

The disposition effect is the irrational tendency to realize gains too early and hold on to losing stocks for too long. Therefore, it should mainly affect the closing of short positions. As pointed out above, our dataset allows us to estimate the amount of short positions that have been closed, rather than just observing differences in short interest. Therefore, as a first step, we study whether the way in which short sellers close their positions is influenced by their capital gains on these positions. If short sellers are prone to the disposition effect, we would expect them to close a larger fraction of their positions if they hold it at higher (more positive) capital gains overhang (Hypothesis 1).

We report our results in Table 2. The dependent variable is Closing - i.e., the percentage of shares on loan that is returned to lenders during the week. In regression specifications 1 to 4, we conduct weekly panel regressions with week and firm fixed effects. Intuitively, one can think of this regression as a way of investigating the change in the closing of short positions in stock A compared to the change in the closing of short positions in stock B. 
Since short sellers’ trades might be driven by past returns (Diether, Lee and Werner (2009)) and turnover, we control for past stock returns and turnover. In Regressions 1 and 3, we employ exactly the same controls as Grinblatt and Han (2005), which are stock turnover in the past year and past returns over the non-overlapping 1 month, 1 year and 3 year horizons. In regressions 2 and 4, 5 and 6, we add additional controls that are standard in the literature: Market to Book, Size, Amihud Illiquidity, Breadth of Ownership, Institutional Ownership and Number of Analysts. In addition, we also employ short selling specific controls: we control for the number of stocks on loan as a percentage of shares outstanding because larger short positions may be closed faster. We include the average lending fee to control for a potential correlation between lower stock prices and higher borrowing costs. We also control for Average Short Sale Duration - i.e., the average time that short positions are open, as older positions may be more likely to be closed.

We find a positive effect of both definitions of short sale capital gains overhang (SCGO I and SCGO II) on the closing of short positions, significant at the $1 \%$ level. The findings are also economically sizable, as a one standard deviation (10.8\%) increase in SCGO I raises Closing by $0.6 \%$ percentage points $(10.8 \% * 0.058 \approx 0.6 \%)$, or approximately $5 \%$ relative to its median $\left(\frac{0.6 \%}{13 \%} \approx 5 \%\right)$. In regressions 5 and 6 , we find very similar coefficients using FamaMacbeth regressions rather than a panel set-up. Overall, our results indicate that short sellers are more likely to close positions in which they are holding positive capital gains, consistent with the disposition effect.

We now try to calibrate the importance of the disposition effect for short sellers using as a benchmark the disposition effect of retail investors (Odean (1998)). Since Odean (1998) has 
individual positions, our measures are not directly comparable, but we nonetheless try a rough approximation. Odean (1998) reports the "percentage of gains realized” (PGR) and "percentage of losses realized" ( $P L R)$, where $P G R(P L R)$ is defined as the percentage of open (long) positions with positive (negative) capital gains that are sold. The fact that PGR is significantly greater than PLR shows the existence of the disposition effect. Our variable Closing captures the percentage of positions that have been closed. The fact that more positions are closed the higher the capital gains, implies that also for short sellers PGR is larger than PLR. For positive capital gains, the average capital gain of short sellers is $8.7 \%$. For negative capital gains, the average capital gain is $-6.5 \%$.

These figures, combined with our regression coefficient of 0.058 , imply that for short sellers the percentage of gains realized (PGR) is approximately 0.8 percentage points higher than the percentage of loss realized (PLR) $((8.7 \%+6.5 \%) * 0.058=0.8 \%)$. In Odean $(1998)$ this difference is $5 \%$, implying that individual trader experience a disposition effect which is roughly 6 times stronger than the disposition effect of short sellers ${ }^{4}$. However, this is only a rough estimate, since the underlying data are very different. It is not surprising that the average short seller is less affected by the disposition effect, given that these traders are more sophisticated and a subset of them trade algorithmically or use long-short strategies and therefore are not affected by the disposition effect.

\footnotetext{
${ }^{4}$ We take the PLR and PGR figures from Odean (1998) Table 1. The average of PLR is 9.8\%, the average of PGR is $14.8 \%$, therefore they are comparable in size to our Closing variable, which has a median of $13 \%$.
} 


\subsection{In which situations is the bias the strongest?}

In this section, we further refine our analysis by focusing on the subsamples in which we expect the relationship between the closing of short position and short sellers' capital gains to be stronger. This analysis has two goals. First, it provides further evidence that this behavior is indeed driven by the disposition effect. Second, it further qualifies the range of impact of such a bias on professional and informed investors.

We consider three different events. First, we study whether our results are stronger if a larger fraction of short sellers is exposed to behavioral biases. We know that algorithmic traders, who we would not expect to be influenced by behavioral biases, also engage in short selling. A common strategy of algorithmic traders is to trade on the momentum anomaly, i.e. to go long past winners and short past losers. The returns to momentum strategies are very negatively skewed, i.e. they make money in normal times, but infrequently deliver highly negative returns (Daniel and Moskowitz (2013)). An extreme example on such negative returns was the momentum crash in 2009 after which many algorithmic traders went out of business (Daniel and Moskowitz (2013)). Thus, following the momentum crash we expect a lower percentage of short sales to be undertaken by algorithms. We hypothesize that the increased fraction of human traders amongst short sellers leads to a stronger disposition effect behavior after the momentum crash.

We therefore regress Closing on an interaction between SCGO and a dummy variable equal to 1 after the momentum crash. The results of this analysis are reported in Regressions 1 and 2 of Table 3. We report results for both measures of short sale capital gains overhang, but limit our attention to our main specification (full controls with week and firm fixed effects). We find 
positive regression coefficients for both measures of short sale capital gains: the effect of SCGO I on Closing doubles after the momentum crash and the increase is statistically very significant, the effect of SCGO II on Closing only increases by $27 \%$, which is still important economically, but statistically insignificant. Overall, these results imply that after the momentum crash - when a larger fraction of short sales are undertaken by human traders - the relationship between capital gains and the closing of short positions is stronger. This finding is consistent with our results being driven by the disposition effect.

Next, we focus on mergers. Around mergers, short sales are not only used for directional bets, but also for long-short strategies. Indeed, when a company is engaged in a merger, a common long-short strategy is merger arbitrage in which the arbitrageur bets on convergence between the stock prices of the target and the acquirer. In this case, the behavior will be different as short sellers will see their potential loss/gain of the short position on the bidder company as part of an overall strategy that also involves the long position on the target company. Thus, they will combine the profits and losses of the long and short leg of the strategy. This implies that our short sell capital gains variable will not be informative for the potential disposition effect related to the short position. Accordingly, we would expect the positive relationship between SCGO and the closing of the short positions to drop during a merger.

We test this idea by regressing Closing on an interaction between SCGO and a dummy variable, which is equal to one between the announcement and the completion of a merger or acquisition in which the company is either the acquirer or the target. We report the results in Regressions 3 and 4 of Table 3 Panel A. We find a negative coefficient on this interaction, 
suggesting that short sellers condition their closing of positions less on their capital gains during times of a merger. The decrease in the effect of SCGO on Closing is approximately $50 \%-100 \%$ depending on the measure. This finding has two implications. First, it is consistent with our results being driven by the disposition effect. Second, it suggests that our results are not caused by short sellers engaging in long-short strategies, but rather that long-short strategies work against us finding an effect of SCGO on the closing of short positions.

The third set of analysis is based on the cost of keeping the short position open. The disposition effect predicts that a trader holds open a losing position for too long. Holding open a short position is costly as the short seller must pay the lending fee to the security owner and faces the funding risk to roll over the position. Thus, we expect short sellers facing higher costs to be less affected by the disposition effect, as being biased is more costly for them. We examine this idea by interacting SCGO with a dummy variable equal to one when a stock is "special" - i.e., has a lending fee of over 100bp per year. This interaction comes in (insignificantly) negative, showing that we observe somewhat less "disposition effect behavior” in stocks with high lending fees.

In Panel B, we extend this analysis by studying other firm characteristics that are generally associated with shorting being more costly or difficult. Indeed, we find a significantly weaker effect of SCGO on Closing for smaller firms, more illiquid stocks and stocks with lower institutional ownership. These are exactly the stocks for which shorting is more expensive /difficult.

These findings not only support our working hypothesis, but they also rule out the following alternative explanation for the positive relationship between Closing and SCGO: Management 
or long investors might try to force short sellers to close their positions (Lamont (2012)). If they are more likely to do so after stock prices have fallen, it might provide an alternative explanation, because SCGO is negatively correlated with returns. However, this behavior is much more likely to work for stocks that are hard to borrow - i.e., small, illiquid and low institutional ownership stocks - while these are the very stocks in which our results are actually weakest. This suggests that this alternative explanation of our findings is not true.

Taken together, the results in this section, are consistent with the positive relationship between SCGO and Closing being driven by the disposition effect rather than some alternative explanations, thereby confirming our Hypothesis 1.

\subsection{Do short sellers exhibit skill in closing their short positions?}

In the remainder of the paper, we will focus on Hypothesis 2. As we outlined above, finding support for this hypothesis confirms both the equilibrium market impact of short sellers and shows that their tendency to close winning positions and hold open losing positions is actually behavioral.

But before we turn to the question of whether short sellers lose money from conditioning their closing of positions on their capital gains, we first investigate whether short sellers on average are profitable in closing their short positions. We do this because our main point is to show that informed traders are subject to behavioral biases. Several studies show that short sales are informed (e.g., Cohen, Diether and Malloy (2007), Boehmer, Jones and Zhang (2008)). However, it is not clear whether this implies that short sellers are also skillful in closing their short positions - i.e., whether they also have positive private information rather than just 
negative. Therefore, we first want to confirm that their closing of short positions is informed in general, before we look at whether it is affected by any biases.

To study the profitability of short sellers' closing of positions, we measure how Closing predicts future returns. The shorting of a stock is profitable if it is followed by a negative stock return. Similarly, a profitable closing of a short position will be followed by a positive return, as the closing prevents the losses that the short seller would have incurred from the positive return. On the other hand, a negative return after the closing of a short position implies that it was closed too early and that the short seller foregoes potential profits.

Therefore, we study how the closing of short positions predicts future returns. We present our results in Table 4. We employ Fama-Macbeth regressions estimated at weekly frequency. This regression set-up is adequate for dependent variables such as returns that have a large time fixed effect and cross-sectional correlation, but little autocorrelation (Petersen (2009)). In Regressions 1 and 2, we regress the weekly return on Closing in the prior week. In Regressions 3 and 4, we instead use a dummy variable equal to 1 if Closing is above the median. In all these cases, we observe a positive relation, which is significant at the $1 \%$ level. An increase in closing by $20 \%$ (one standard deviation) predicts a positive one-week return of 4.2 basis points, which corresponds to a yearly return of $2.2 \%$. Stocks with above median closing experience stock returns that are 7 basis points higher per week, which is 3.7\% per year.

These results suggest that short sellers on average exhibit skill in closing their positions. However, just because short sellers are skillful on average does not mean that they are not influenced by a bias as well. As we will show in the next section, their closing of short positions would be even more profitable if they did not condition it on their capital gains. 


\section{Does short sellers' disposition effect have an effect on stock prices?}

In this section, we investigate the stock price implications of the disposition effect of short sellers. To do this, we follow the approach of Grinblatt and Han (2005) and test whether short sale capital gains overhang (SCGO) predicts stock returns negatively. As we outlined in the hypothesis section, finding that SCGO negatively predicts stock returns also implies that the behavior is indeed a behavioral bias rather than a profit-maximizing strategy. We conduct both a regression analysis and a portfolio analysis.

\subsection{Regression Analysis}

We start by replicating the findings of Grinblatt and Han (2005) within our data. We present the results in Regression 1 and 2 of Table 5. Following Grinblatt and Han (2005), we run FamaMacbeth regressions of the current weekly return on the capital gains overhang (LCGO) at the beginning of the prior week, using the extra week lag to avoid confounding micro-structure effects. In Regression 1, we use the same set of controls as Grinblatt and Han (2005), namely stock turnover in the past year and past returns over the non-overlapping 1 month, 1 year and 3 year horizons as well as company size. In Regression 2, we add Market to Book, Amihud Illiquidity, Breadth of Ownership, Institutional Ownership, Number of Analysts, Average Lending Fee and Average Short Sale Duration as additional control variables. As in their paper, we find a positive association between capital gains and future returns consistent with return predictability based on the capital gains of long traders. The result is both statistically and economically significant. A one standard deviation increase (27.6\%) in LCGO corresponds to a positive return of 14 basis points per week $(27.6 \% * 0.0051=0.14 \%)$ or approximately $7.5 \%$ per year. This finding is significant at the $1 \%$ level. 
Next, we study whether the capital gains overhang of short sellers has a similar price impact. The results are reported in Regressions 3 to 6 of Table 5. We run the same regression as above, but replace the capital gains of long traders ( $L C G O)$ with our variables for short sale capital gains overhang (SCGO I and SCGO II). Given that short sellers need to buy a stock to close a position, we would expect a negative relationship between SCGO and future capital gains according to our adaption of the model in Grinblatt and Han (2005). And indeed, both SCGO I and SCGO II predict negative future returns at a $1 \%$ confidence level. The result is also economically significant. A one standard deviation (10.8\%) increase in SCGO I predicts a negative return of 8 basis points per week $(10.8 \% * 0.0070 \approx 0.08 \%$ ) or $4.2 \%$ per year. This result confirms our hypothesis 2 .

The important message from this result is that short sellers do not act as arbitrageurs leaning against the mispricing caused by the disposition effect of long traders. Rather, their own disposition effect makes them trade generally in the same direction as long traders. When prices have fallen and long traders are reluctant to sell, because they have a capital loss, short sellers are likely to report capital gains and therefore more likely to close their positions - i.e. buy back the stock - thereby increasing the upwards price pressure. Similarly, when prices have gone up and long traders want to secure their gains by selling, short sellers are less likely to close, as they are likely to be at a capital loss. Thus, their behavioral biases limits short sellers' ability to arbitrage away the mispricing caused by long investors’ disposition effect.

This argument might however also raise worries about our methodology. As SCGO and LCGO are negatively correlated, it may be that SCGO just acts as a proxy for the capital gains of long traders. To address this issue, we run a "horse-race" between the two capital gains 
overhang variables. We repeat the regression set-up of Table 5, but regress the return on both SCGO and $L C G O$. It is important to note that in this analysis, we have two separate proxies for capital gains overhang: one for short sellers and one for the long investors.

We report the results in Table 6 . We find that both variables stay significant at the $5 \%$ threshold, but, as expected, the effect of each individual variable is reduced. Controlling for SCGO, one standard deviation increase in LCGO predicts a positive return of 12 basis points per week $(27.6 \% * 0.0042=0.12 \%)$ or $6.4 \%$ per year. Controlling for LCGO, one standard deviation increase in SCGO predicts a negative return of 5 basis points $(10.8 \% * 0.0048 \approx$ $0.05 \%$ ) or $2.8 \%$ per year. While the effect of SCGO on future returns is smaller than the effect of LCGO, it is relatively large compared to the fact that short sellers are less biased and constitute a smaller fraction of the market. To summarize, we find that both SCGO and LCGO have predictive powers on future returns, suggesting that prices are driven by both the disposition effect of short sellers and the disposition effect of long traders.

It is important to underline that this finding also shows that it is irrational for short sellers to close more positions with high SCGO, because they miss out on the subsequent negative return. This suggests that they are indeed subject to the disposition effect rather than employing a profit-maximizing strategy based on private information.

\subsection{Portfolio Analysis}

We now focus on whether the predictive power of SCGO can be converted into a profitable trading strategy. This analysis is meant to provide a further robustness check of the previous results. Moreover, it will show that the disposition effect of short sellers leads to price distortions that can be exploited for profitable trading. 
We employ the method of portfolio analysis. At the beginning of each week, we assign stocks to 16 portfolios by simultaneously sorting them on the past 12 week cumulative return (i.e., momentum) and our measure of short sale capital gains overhang. As in Grinblatt and Han (2005), we employ this double sort to control for the general momentum effect. We use a shorter window of only 12 weeks, because short sellers have a shorter investment horizon than long traders (see Section 3.4).

We report our results in Table 7. The disposition effect might have a lower effect in January due to tax reasons as traders have an incentive to realize losses before the end of the fiscal year in December (e.g., Grinblatt and Han (2005)) and also the momentum anomaly is usually not present in January (Jegadeesh and Titman (1993)). Therefore, we present our results for both the entire year and excluding January. We display both the raw returns of the different portfolios, as well as the 3 Fama and French (1993) factor-adjusted alphas. We do not add the momentum factor, since we already control for momentum through the double sort.

The trading strategy that we are interested in goes long in the $25 \%$ of stocks with the highest SCGO and short in the $25 \%$ of stocks with the lowest SCGO within each past return quartile. This strategy yields statistically significant negative returns in three out of four cases. ${ }^{5}$ Only in the case of very negative past returns, the negative returns are not significant. This might be due to the fact that the disposition effect of short sellers is mainly effective through the area of losses - i.e. that short sellers hold losing positions too long more than they close winning positions too early. In the other three cases, the trading strategy yields very large negative returns. Excluding January, the 3-factor alphas range from 12 basis points per week to 47 basis

\footnotetext{
${ }^{5}$ We set up the long-short portfolio to obtain negative returns, so that our results are more easily compared to Grinblatt and Han (2005). A trader would want to set up the portfolio in the opposite way so that it generates positive returns.
} 
points per week, which corresponds to yearly alphas of $6.4 \%$ to $26 \%$. This finding is significant at the $1 \%$ level for all but one quartile. If we include January, the alphas are slightly lower with 8 to 30 basis points per week or $4.4 \%$ to $17 \%$ per year. These returns are significant at least at the $5 \%$ level in all but one quartile. We find similar though slightly weaker results focusing on returns instead of alphas.

In Figure 1, we plot the cumulative returns of these portfolios to get a better idea how the portfolios perform over time. Specifically, we focus on stocks in the highest $25 \%$ by prior 12 week return, where the strategy works best. We examine the portfolio that invests in the $25 \%$ of stocks with the highest Short Sale Capital Gains Overhang I (SCGO_I 1 - R1 in Table 6) and the portfolio that invests in the $25 \%$ of stocks with the highest Short Sale Capital Gains Overhang I (SCGO_I 1 - R4 in Table 6). While the two portfolios are clearly correlated and move with the overall market, we see that the Low Short Sale Capital Gains Portfolio continuously outperforms the High Short Sale Capital Gains Portfolio. The gap between the two portfolios continuously widens. If we invest $\$ 100$ dollar in both portfolios at the beginning of our sample period, we get $\$ 164$ for the Low SCGO Portfolio, but only \$62 for the High SCGO Portfolio.

Next, in Figure 2, we examine the performance of the long-short strategies. In each of these strategies, the trader goes long in the $25 \%$ of stocks with the highest SCGO and short in the $25 \%$ of stocks with the lowest SCGO. We plot the long-short strategy for the top quartile by prior 12 weeks returns, which is the long-short variant of Figure 1. We also examine a strategy that invests equally into the long-short portfolio for the top three past return quartiles and one that invests equally into the long-short portfolio of all four past return quartiles (both with 
weekly rebalancing). As predicted by our hypotheses, all long-short strategies are continuously losing money. The strategy loses money most effectively in the top past return quartile, where a \$100 investment is turned into \$39 - i.e., a 61\% loss! But even a strategy based on investing equally into all the four return quartiles delivers only $\$ 57$ - i.e., a 47\% loss! Finally, in Panels C and D of Table 6, we repeat the analysis with our second proxy of short sale capital gains overhang (SCGO II). Also in this case, we find significant negative returns of our strategy for 3 out of 4 past return quartiles in the non-January sample. Returns are somewhat smaller, but still very large in economic terms with up to 34 bp a week or $19 \%$ a year. As a caveat, one has to take into account that there will be substantial trading costs in implementing these strategies as portfolios are rebalanced once a week. Overall, the portfolio analysis underlines the fact that large capital gains of short sellers predict negative stock returns and that it is possible to construct a trading strategy based on this predictability that consistently yields positive returns.

\section{Robustness Check: Alternative past return controls}

Our Short Sale Capital Gains Overhang variables are inevitably correlated with past returns. Therefore, we control for past returns in all our regressions. We choose the same controls as Grinblatt and Han (2005) and control for non-overlapping returns at the 1 month, 1 year and 3 year horizon. However, one may be worried that these returns are not enough and Short Sale Capital Gains Overhang simply proxies for past returns at a different horizon.

To address this issue, we report robustness checks in Table 8 in which we replace the 1 year return variable with return variables for each individual quarter. More specifically, we include returns for weeks $\mathrm{t}-4$ to $\mathrm{t}-1, \mathrm{t}-12$ to $\mathrm{t}-5, \mathrm{t}-26$ to $\mathrm{t}-13$, $\mathrm{t}-39$ to $\mathrm{t}-27, \mathrm{t}-52$ to $\mathrm{t}-40$ and $\mathrm{t}-156$ to $\mathrm{t}-52$. In Panel A, we repeat the main regressions of Table 2 and in Panel B, we repeat the main 
regressions of Table 5 and Table 6. In all these cases, our results stay significant and the size of our effects actually increases. This finding suggests that our results are not driven by inappropriate controls for past returns.

\section{Conclusion}

We study whether traders traditionally considered to be rational, sophisticated and better informed - the short sellers - suffer from behavioral biases and whether this affects the stock market. We focus on the disposition effect (Shefrin and Statman (1985)). Using a new dataset on stock lending for all U.S. stocks from 2004 to 2010, we are able to examine the closing of short positions. We show that short sellers exhibit the disposition effect - i.e. they hold on to their losing positions too long and close their winning positions too early. We establish this by demonstrating two facts: first, the closing of short sale positions is strongly related to a proxy of Short Sale Capital Gains Overhang (SCGO). Second, SCGO is negatively related to future stock returns, which implies that short sellers are losing money by conditioning their closing of short positions on SCGO. The negative relationship between SCGO and future stock returns is consistent with the model of Grinblatt and Han (2005) adapted to short sellers. It suggests that short sellers, rather than arbitraging away the mispricing induced by the disposition effect, are biased to trade in the same direction as long investors. In this sense, short sellers' disposition effect can be thought of as a limit to arbitrage.

Our findings have important normative implications. Indeed, if short sellers themselves are irrational, then the classic view of short selling as an arbitrage device is questionable. If short sellers are a source of market frictions as opposed to their deterrent, any regulation limiting short selling activity may have unintended consequences. Since the disposition effect induces 
underreaction to news, it reduces stock market volatility. Thus banning disposition prone short sellers from trading may increase rather than reduce the speed and amplitude of market gyrations. 


\section{References}

Aitken, Michael J., Alex Frino, Michael S. McCorry, and Peter L. Swan, 1998, Short Sales Are Almost Instantaneously Bad News: Evidence from the Australian Stock Exchange, The Journal of Finance 53, 2205-2223.

Asquith, Paul, and Lisa K. Meulbroek, 1995, An empirical investigation of short interest, Working Paper .

Barber, Brad M., and Terrance Odean, 2000, Trading Is Hazardous to Your Wealth: The Common Stock Investment Performance of Individual Investors, The Journal of Finance 55, 773-806.

Barberis, Nicholas, Ming Huang, and Tano Santos, 2001, Prospect Theory and Asset Prices, The Quarterly Journal of Economics 116, 1-53.

Barberis, Nicholas, and Ming Huang, 2001, Mental Accounting, Loss Aversion, and Individual Stock Returns, The Journal of Finance 56, 1247-1292.

Barberis, Nicholas, and Wei Xiong, 2009, What Drives the Disposition Effect? An Analysis of a Long-Standing PreferenceBased Explanation, The Journal of Finance 64, 751-784.

Ben-David, Itzhak and David Hirshleifer, 2012, Are Investors Really Reluctant to Realize Their Losses? Trading Responses to Past Returns and the Disposition Effect, Review of Financial Studies 25, 2485-2532.

Berkelaar, Arjan B., and Roy R. P. Kouwenberg, 2000, Dynamic Asset Allocation and Downside-Risk Aversion, Econometric Institute Report No. EI 2000-12/A.

\section{Boehmer Ekkehart, Zsuzsa R. Huszar, and Bradford. Jordan, 2010, The Good News in Short}

Interest, Journal of Financial Economics 96, 80-97. Boehmer, Ekkehart, Charles M. Jones, and Xiaoyan Zhang, 2008, Which Shorts Are Informed? The Journal of Finance 63, 491-527.

Boehmer, Ekkehart, and Juan Wu, 2013, Short Sellling and the Price Discovery Process, Review of Financial Studies 26, 287-322.

Bris, Arturo, William N. Goetzmann, and Ning Zhu, 2007, Efficiency and the Bear: Short Sales and Markets Around the World, The Journal of Finance 62, 1029-1079.

Chen, Joseph, Harrison Hong, and Jeremy C. Stein, 2002, Breadth of ownership and stock returns, Journal of Financial Economics 66, 171-205.

Cohen, Lauren, Karl B. Diether, and Christopher J. Malloy, 2007, Supply and Demand Shifts in the Shorting Market, The Journal of Finance 62, 2061-2096.

Coval, Joshua D., and Tobias J. Moskowitz, 1999, Home Bias at Home: Local Equity Preference in Domestic Portfolios, The Journal of Finance 54, 2045-2073.

Coval, Joshua D., and Tyler Shumway, 2005, Do Behavioral Biases Affect Prices?, The Journal of Finance 34, 1-34.

Diether, Karl B., Kuan-Hui Lee, and Ingrid M. Werner, 2009, Short-Sale Strategies and Return Predictability, Review of Financial Studies 22, 575-607.

Diether, Karl B., Christopher J. Malloy, and Anna Scherbina, 2002, Differences of Opinion and the Cross Section of Stock Returns, The Journal of Finance 57, 2113-2141.

Engelberg, Joseph E., Adam V. Reed, and Matthew C. Ringgenberg, 2012, How are shorts informed?: Short sellers, news, and information processing, Journal of Financial Economics 105, 260-278.

Engelberg, Joseph E., Adam V. Reed, and Matthew C. Ringgenberg, 2014, Short Selling Risk, Working Paper.

Fama, Eugene F., and Kenneth R. French, 1993, Common risk factors in the returns on stocks and bonds, Journal of Financial Economics 33, 3-56.

Frazzini, Andrea, 2006, The Disposition Effect and Underreaction to News, The Journal of Finance 61, 2017-2046.

Geczy, Christopher C., David K. Musto, and Adam V. Reed, 2002, Stocks are special too: an analysis of the equity lending market, Journal of Financial Economics 66, 241-269.

Genesove, David, and Christopher Mayer, 2001, Loss Aversion and Seller Behavior: Evidence from the Housing Market, The Quarterly Journal of Economics 116, 1233-1260. 
Gomes, Francisco J., 2005, Portfolio Choice and Trading Volume with Loss-Averse Investors, The Journal of Business 78 , 675-706.

Grinblatt, Mark, and Bing Han, 2005, Prospect theory, mental accounting, and momentum, Journal of Financial Economics 78, 311-339.

Grinblatt, Mark, and Matti Keloharju, 2001, What Makes Investors Trade? The Journal of Finance 56, 589-616.

---. 2000, The Investment Behavior and Performance of Various Investor-Types: A Study of Finland's Unique Data Set. Journal of Financial Economics 55, 43-67.

Heath, Chip, Steven Huddart, and Mark Lang, 1999, Psychological Factors and Stock Option Exercise, The Quarterly Journal of Economics 114, 601-627.

Huberman, Gur, 2001, Familiarity Breeds Investment, Review of Financial Studies 14, 659-680.

Jegadeesh, Narasimhan and Sheridan Titman, 1993, Returns to Buying Winners and Selling Losers: Implications for Stock Market Efficiency, The Journal of Finance 48, 65-91.

Jin, Li, and Anna Scherbina, 2011, Inheriting Losers, Review of Financial Studies 24, 786-820.

Jones, Charles M., and Owen A. Lamont, 2002, Short-sale constraints and stock returns, Journal of Financial Economics 66, 207-239.

Lamont, Owen A., 2012, Go Down Fighting: Short Sellers vs. Firms, Review of Asset Pricing Studies 2, 1-30.

Locke, Peter R., and Steven C. Mann, 2005, Professional trader discipline and trade disposition, Journal of Financial Economics 76, 401-444.

Miller, Edward M., 1977, Risk, Uncertainty, and Divergence of Opinion, The Journal of Finance 32, 1151-1168.

Odean, Terrance, 1998, Are Investors Reluctant to Realize Their Losses? The Journal of Finance 53, 1775-1798.

---. 1999, Do Investors Trade Too Much? American Economic Review 89, 1279-1298.

Petersen, Mitchell A., 2009, Estimating Standard Errors in Finance Panel Data Sets: Comparing Approaches, Review of Financial Studies 22, 435-480.

Saffi, Pedro A. C., and Kari Sigurdsson, 2011, Price Efficiency and Short Selling, Review of Financial Studies 24, 821-852.

Senchack, A. J.,Jr., and Laura T. Starks, 1993, Short-Sale Restrictions and Market Reaction to Short-Interest Announcements, The Journal of Financial and Quantitative Analysis 28, pp. 177-194.

Shefrin, Hersh, and Meir Statman, 1985, The Disposition to Sell Winners Too Early and Ride Losers Too Long: Theory and Evidence, The Journal of Finance 40, 777-790.

Shleifer, Andrei and Robert W. Vishny, 1997, The Limits of Arbitrage, The Journal of Finance 52, 35-55.

Thaler, Richard, 1980, Toward a positive theory of consumer choice, Journal of Economic Behavior \& Organization 1, 3960 .

Thornock, Jacob R., 2013, The Effects of Dividend Taxation on Short Selling and Market Quality, Accounting Review, Forthcoming .

von Beschwitz, Bastian, Oleg Chuprinin and Massimo Massa, 2015, Why Do Short Sellers Like Qualitative News?, Journal of Quantitative and Financial Analysis, forthcoming.

Weber, Martin, and Colin F. Camerer, 1998, The disposition effect in securities trading: an experimental analysis, Journal of Economic Behavior \& Organization 33, 167-184. 


\section{Figure 1: High vs. Low Short Sale Capital Gains Portfolios}

In this figure we report cumulative portfolio returns for two portfolios: The High Short Sale Capital Gains Portfolio invests in the beginning of each week in those stocks that are in the top quartile (top 25\%) by prior week Short Sale Capital Gains Overhang (SCGO I). The Low Short Sale Capital Gains Portfolio invests in the beginning of each week in those stocks that are in the bottom quartile (lower $25 \%$ ) by prior week Short Sale Capital Gains Overhang (SCGO I). In both portfolios, we only consider those stocks that are in the top quartile (top 25\%) by past 12 weeks stock return. Thus the High Short Sale Capital Gains Portfolio corresponds to the SCGO_I 4 - R4 portfolio in Panel B of Table 6, while the Low Short Sale Capital Gains Portfolio corresponds to the SCGO_I 1 - R4 portfolio in Panel B of Table 6. Portfolio returns are set to zero during weeks that include the period of the short sale ban (September 15, 2008 to October 10, 2008).

\section{Cumulative Portfolio Returns}

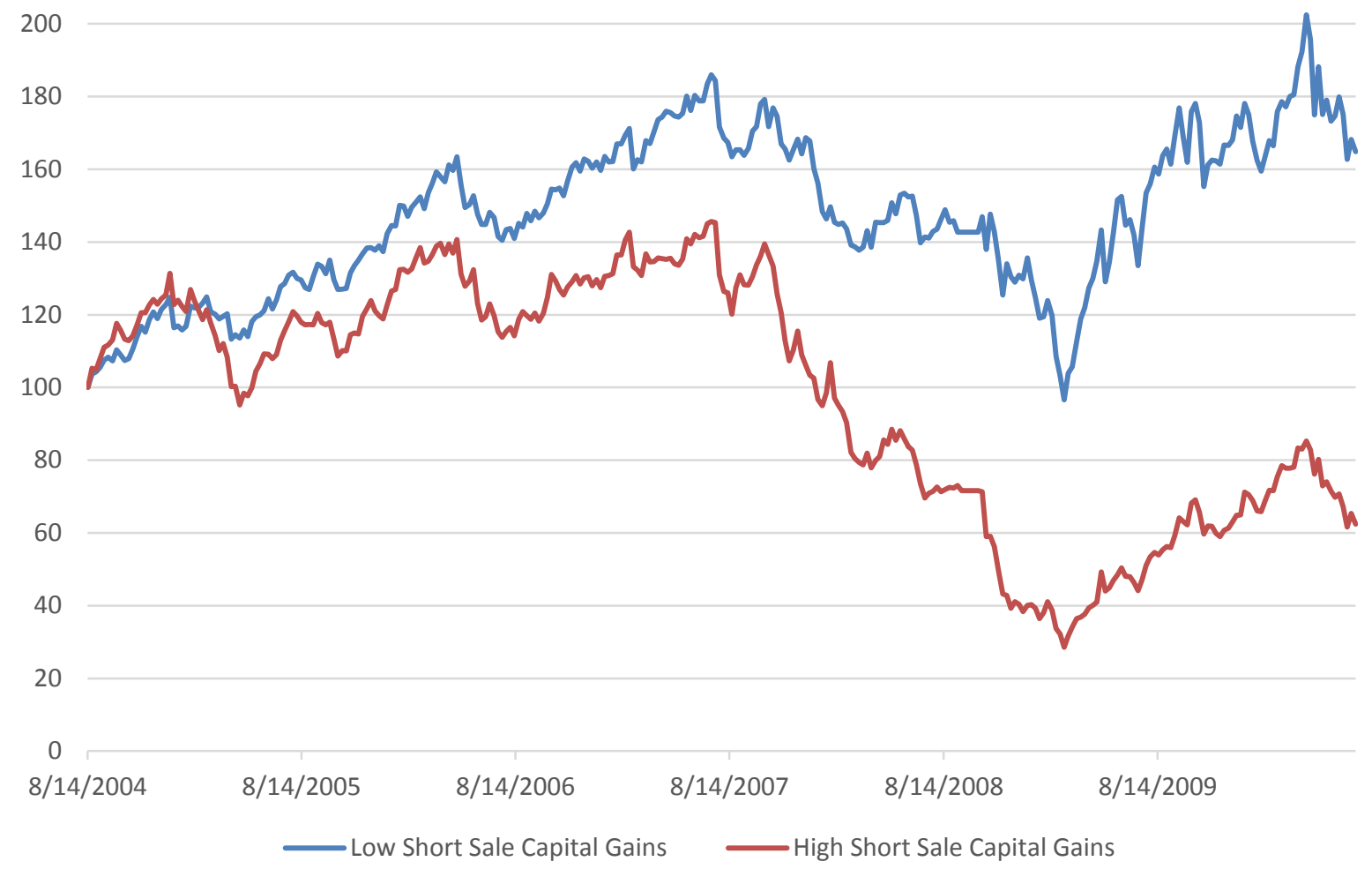




\section{Figure 2: Long-Short Portfolios by Short Sale Capital Gains Overhang}

In this figure we report cumulative portfolio returns for portfolios that are rebalanced weekly. The portfolios are long in stocks that are in the Top Quartile (top 25\%) by prior week Short Sale Capital Gains Overhang (SCGO I) and short in stocks that are in the bottom quartile (lower 25\%) by prior week Short Sale Capital Gains Overhang (SCGO I). For the Top Return Quartile Portfolio, we only consider those stocks that are in the top quartile (top 25\%) by past 12 weeks stock return. Thus, it corresponds to the "SCGO I 4 minus SCGO I 1 - R4" portfolio in Table 6. For the Top 3 Return Quartile, we invest equally in this portfolio strategy for the three highest quartiles by past 12 weeks stock returns. For All Return Quartiles, we invest equally in this portfolio strategy for all four past return quartiles. Portfolio returns are set to zero during weeks that include the period of the short sale ban (September 15, 2008 to October 10, 2008).

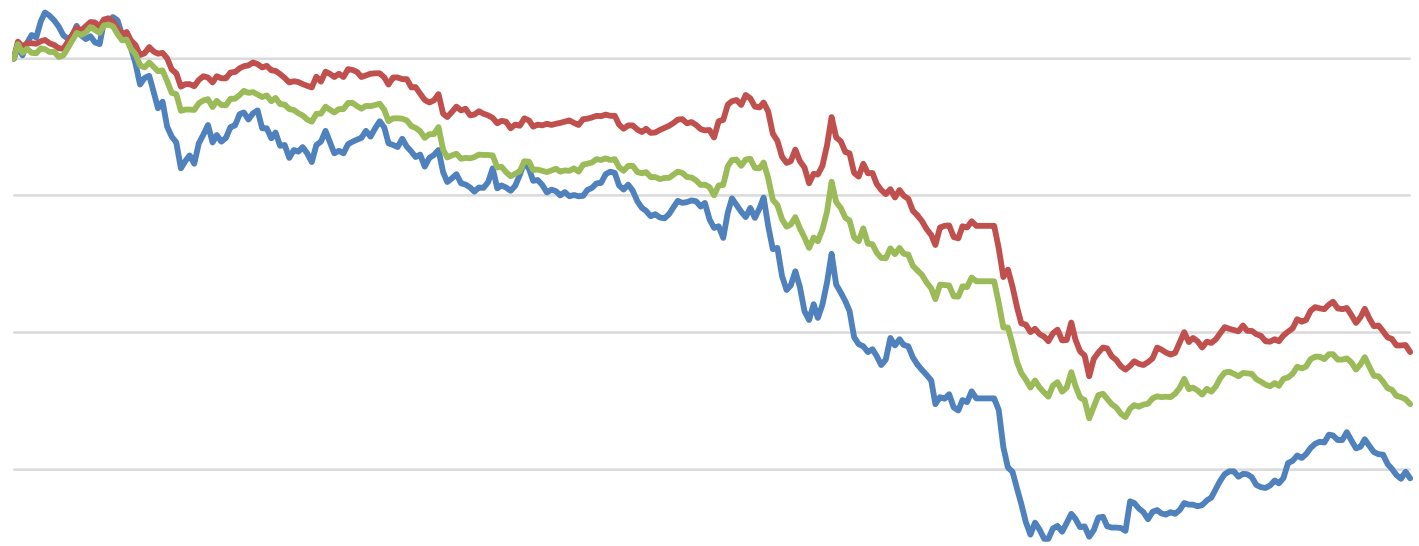

20

0 


\section{Table 1: Summary Statistics}

In Panel A we list the company specific variables for the 6134 companies in our sample. We compute those at the company-year level. Breadth of Ownership is defined as number of institutions holding the stock divided by total number of reporting institutions. Number of Analysts is the number of analysts on IBES that issue an earnings forecast for the stock. Institutional Ownership is the percentage of shares held by institutions. In Panel B we list summary statistics of market variables for the 1,231,405 company-weeks in the period of August 2004 to June 2010. Loaned Stocks is the number of stocks on loan at the end of the week divided by shares outstanding. Shorting is the number of shares newly shorted during the week divided by shares outstanding. Closing is the number of shares returned to lenders during the week divided by shares on loan at the beginning of the week. Average Short Sale Duration is the average number of days that the short positions are open. Average Lending Fee is the average cost to borrow that stock in basis points per year. SCGO I and SCGO II (Short Sale Capital Gains Overhang variables) are both defined as $\frac{\text { Reference Price-Price }}{\text { Reference Price }}$, but with different proxies for the Reference Price (see Section 3.2 and Appendix 1 for a more detailed description). They proxy the average capital gains with which short sellers hold their position in the stock. LCGO (Long Capital Gains Overhang) is defined as $\frac{\text { Price-Reference Price }}{\text { Reference Price }}$, where the reference price is defined recursively as: Reference price ${ }_{t}=\frac{\text { Trading volume }_{t}}{\text { Shares Outstanding }_{t}} *$

Price $_{t}+\left(1-\frac{\text { Trading volume }_{t}}{\text { Shares Outstandingt }}\right) *$ Reference Price $_{t-1}$. This variable measures the average capital gains of traders that are long. We remove weeks that include the period of the short sale ban (September 15, 2008 to October 10, 2008).

Panel A: Company Variables

\begin{tabular}{|c|c|c|c|c|c|}
\hline & Median & Mean & $25^{\text {th }}$ Percentile & $75^{\text {th }}$ Percentile & $\begin{array}{c}\text { Standard } \\
\text { Deviation }\end{array}$ \\
\hline Market capitalization in m \$ & 350 & 2507 & 102 & 1328 & 7614 \\
\hline Market to Book & 1.94 & 2.78 & 1.25 & 3.22 & 2.75 \\
\hline Breadth of Ownership (\%) & 2.98 & 4.81 & 0.92 & 6.13 & 5.87 \\
\hline Number of Analysts & 3 & 5 & 0 & 7 & 6.1 \\
\hline Institutional Ownership (\%) & 52.8 & 50.7 & 23.2 & 78.2 & 30.2 \\
\hline
\end{tabular}

Panel B: Market variables

\begin{tabular}{|c|c|c|c|c|c|}
\hline & Median & Mean & $25^{\text {th }}$ Percentile & $75^{\text {th }}$ Percentile & $\begin{array}{l}\text { Standard } \\
\text { Deviation }\end{array}$ \\
\hline Loaned Stocks (\%) & 1.70 & 3.89 & 0.20 & 5.31 & 5.39 \\
\hline Shorting (\%) & 0.24 & 0.57 & 0.03 & 0.76 & 0.84 \\
\hline Closing (\%) & 12.95 & 18.96 & 5.39 & 25.00 & 20.19 \\
\hline Average Lending Fee (bp) & 14.32 & 71.30 & 9.41 & 26.96 & 173.87 \\
\hline Average Short Sale Duration (days) & 62 & 77 & 34 & 99 & 66 \\
\hline Weekly Turnover (\%) & 2.52 & 4.20 & 0.99 & 5.09 & 8.14 \\
\hline Weekly Return (\%) & 0.00 & 0.19 & -2.96 & 3.09 & 6.55 \\
\hline SCGO I (\%) & 0.00 & 0.93 & -4.03 & 4.61 & 10.82 \\
\hline SCGO II (\%) & -0.30 & -0.12 & -5.19 & 4.86 & 10.75 \\
\hline LCGO (\%) & 1.81 & 1.00 & -13.45 & 15.02 & 27.61 \\
\hline
\end{tabular}




\section{Table 2: Do short sellers hold losers and sell winners?}

This table contains the results of weekly panel regressions that examine the effect of Short sale Capital Gains Overhang (SCGO) on the closing of short sale positions from August 2004 to June 2010, excluding the period of the short sale ban (September 15, 2008 to October 10, 2008). The dependent variable is Closing (percentage of loaned shares that are returned to lenders during the week). The explanatory variable of interest is SCGO at the beginning of the week. We show results of SCGO I and SCGO II respectively. Return t-k to t-j is the average weekly return in the specified weeks. Turnover t-52 to t-1 is the weekly average of number of shares traded divided by shares outstanding. Other control variables are defined in Appendix 1. Fama-Macbeth regressions are at weekly frequency. In the OLS regressions, standard errors are two-way clustered at the firm and week level. We report average $\mathrm{R}^{2}$ for the Fama-Macbeth regression and adjusted $\mathrm{R}^{2}$ for the OLS regressions. T-statistics are below the parameter estimates in parenthesis. *** indicates significance at the $1 \%$ level, ** indicates significance at the $5 \%$ level, and * indicates significance at the $10 \%$ level.

\begin{tabular}{|c|c|c|c|c|c|c|}
\hline & \multicolumn{6}{|c|}{ Closing } \\
\hline & (1) & (2) & (3) & (4) & (5) & (6) \\
\hline SCGO I & $\begin{array}{c}0.0318^{* * *} \\
(2.83)\end{array}$ & $\begin{array}{c}0.0582^{* * *} \\
(5.90)\end{array}$ & & & $\begin{array}{c}0.0539^{* * *} \\
(5.09)\end{array}$ & \\
\hline SCGO II & & & $\begin{array}{c}0.0337^{* * *} \\
(2.93)\end{array}$ & $\begin{array}{c}0.0308^{* * *} \\
(3.19)\end{array}$ & & $\begin{array}{c}0.0311^{* * *} \\
(2.99)\end{array}$ \\
\hline Return $\mathrm{t}-4$ to $\mathrm{t}-1$ & $\begin{array}{l}0.2703^{* * *} \\
(7.61)\end{array}$ & $\begin{array}{c}0.3011^{* * *} \\
(9.88)\end{array}$ & $\begin{array}{c}0.2759^{* * * *} \\
(7.14)\end{array}$ & $\begin{array}{c}0.2532^{* * *} \\
(7.56)\end{array}$ & $\begin{array}{c}0.3347^{* * *} \\
(11.01)\end{array}$ & $\begin{array}{c}0.3038^{* * *} \\
(9.03)\end{array}$ \\
\hline Return $\mathrm{t}-52$ to $\mathrm{t}-5$ & $\begin{array}{c}1.2570^{* * *} \\
(13.29)\end{array}$ & $\begin{array}{c}1.1844^{* * *} \\
(9.92)\end{array}$ & $\begin{array}{c}1.2291^{* * *} \\
(14.57)\end{array}$ & $\begin{array}{c}1.1195^{* * *} \\
(9.33)\end{array}$ & $\begin{array}{c}1.1823^{* * *} \\
(17.29)\end{array}$ & $\begin{array}{c}1.1128^{* * *} \\
(18.18)\end{array}$ \\
\hline Return t-156 to t-53 & $\begin{array}{c}0.4013^{* * *} \\
(2.89)\end{array}$ & $\begin{array}{c}0.5357^{* * *} \\
(3.31)\end{array}$ & $\begin{array}{c}0.4347^{* * *} \\
(3.13)\end{array}$ & $\begin{array}{l}0.5383^{* * *} \\
(3.29)\end{array}$ & $\begin{array}{c}0.4101^{* * *} \\
(6.79)\end{array}$ & $\begin{array}{c}0.4293^{* * *} \\
(7.01)\end{array}$ \\
\hline Turnover t-52 to t-1 & $\begin{array}{c}-0.1144^{* * *} \\
(-3.90)\end{array}$ & $\begin{array}{c}0.1261^{* * *} \\
(3.67)\end{array}$ & $\begin{array}{c}-0.1006^{* * * *} \\
(-3.40)\end{array}$ & $\begin{array}{c}0.1340^{* * *} \\
(3.83)\end{array}$ & $\begin{array}{c}0.3551^{* * *} \\
(27.53)\end{array}$ & $\begin{array}{c}0.3712^{* * *} \\
(27.70)\end{array}$ \\
\hline Market to Book & & $\begin{array}{c}-0.0002 \\
(-0.53)\end{array}$ & & $\begin{array}{c}-0.0001 \\
(-0.34)\end{array}$ & $\begin{array}{c}-0.0009^{* * *} \\
(-11.26)\end{array}$ & $\begin{array}{c}-0.0009^{* * * *} \\
(-10.56)\end{array}$ \\
\hline Size & & $\begin{array}{l}-0.0019 \\
(-0.62)\end{array}$ & & $\begin{array}{l}-0.0033 \\
(-1.07)\end{array}$ & $\begin{array}{c}-0.0071^{* * *} \\
(-7.93)\end{array}$ & $\begin{array}{c}-0.0074^{* * *} \\
(-8.15)\end{array}$ \\
\hline Amihud Illiqudity & & $\begin{array}{c}0.0007^{* * *} \\
(5.03)\end{array}$ & & $\begin{array}{c}0.0006^{* * *} \\
(4.44)\end{array}$ & $\begin{array}{c}0.0002^{* * *} \\
(2.74)\end{array}$ & $\begin{array}{c}0.0002^{* *} \\
(2.49)\end{array}$ \\
\hline Breadth of Ownership & & $\begin{array}{c}0.1462^{* *} \\
(2.15)\end{array}$ & & $\begin{array}{c}0.1590^{* * *} \\
(2.34)\end{array}$ & $\begin{array}{c}0.3934^{* * *} \\
(23.29)\end{array}$ & $\begin{array}{c}0.3933^{* * *} \\
(23.70)\end{array}$ \\
\hline Inst. Ownership & & $\begin{array}{c}0.0317^{* * *} \\
(4.77)\end{array}$ & & $\begin{array}{c}0.0263^{* * *} \\
(3.92)\end{array}$ & $\begin{array}{c}0.0460^{* * *} \\
(9.28)\end{array}$ & $\begin{array}{c}0.0442^{* * *} \\
(9.13)\end{array}$ \\
\hline Number of Analysts & & $\begin{array}{c}-0.0063^{* * *} \\
(-4.88)\end{array}$ & & $\begin{array}{c}-0.0067^{* * *} \\
(-5.09)\end{array}$ & $\begin{array}{c}-0.0034^{* * *} \\
(-6.14)\end{array}$ & $\begin{array}{c}-0.0035^{* * *} \\
(-6.17)\end{array}$ \\
\hline $\begin{array}{l}\text { Average Short Sale } \\
\text { Duration }\end{array}$ & & $-0.0006^{* * *}$ & & $-0.0006^{* * *}$ & $-0.0007^{* * *}$ & $-0.0007^{* * *}$ \\
\hline & & $(-34.32)$ & & $(-33.33)$ & $(-51.64)$ & $(-53.75)$ \\
\hline Average Lending Fee & & $\begin{array}{c}0.0033^{* * * *} \\
(5.35)\end{array}$ & & $\begin{array}{l}0.0038^{* * *} \\
(6.08)\end{array}$ & $\begin{array}{c}0.0016^{* * *} \\
(2.78)\end{array}$ & $\begin{array}{c}0.0023^{* * *} \\
(3.83)\end{array}$ \\
\hline Loaned Stocks & & $\begin{array}{c}-0.0059^{* * *} \\
(-26.94)\end{array}$ & & $\begin{array}{c}-0.0060^{* * *} \\
(-26.89)\end{array}$ & $\begin{array}{c}-0.0085^{* * *} \\
(-46.63)\end{array}$ & $\begin{array}{c}-0.0087^{* * *} \\
(-48.45)\end{array}$ \\
\hline Observations & 951495 & 766355 & 912409 & 734851 & 766355 & 734851 \\
\hline Average $R^{2} /$ Adjusted $R^{2}$ & 0.18 & 0.21 & 0.18 & 0.21 & 0.15 & 0.15 \\
\hline Fama-MacBeth & No & No & No & No & Yes & Yes \\
\hline Firm and Week F. E. & Yes & Yes & Yes & Yes & No & No \\
\hline
\end{tabular}




\section{Table 3: Interactions}

This table contains the results of weekly panel regressions that examine how different factors mediate the effect of Short sale Capital Gains Overhang (SCGO) on the closing of short sale positions. The sample period runs from August 2004 to June 2010, excluding the period of the short sale ban (September 15, 2008 to October 10, 2008). The explanatory variable of interest are SCGO I and SCGO II at the beginning of the week interacted with different variables. We use the following dummy variables as interactions: After Momentum Crash is equal to 1 in weeks after $1^{\text {st }}$ May 2009 and 0 in the weeks before $1^{\text {st }}$ March 2009. Merger is equal to 1 in the weeks between the announcement and completion of a merger (for either acquirers or targets). Specialness is equal to 1 if the value weighted average lending fee is above $100 \mathrm{bp}$. Small Firm is equal to 1 if the firm is below the median of market capitalization in that week. Illiquidity is equal to 1 if the firm is above the median by Amihud Illiquidity. Low Instititutional Ownership is equal to 1 if the firm is below the median in institutional ownership. All regressions include the following control variables that are omitted for brevity: Return $t-4$ to $t-1$, Return $t-52$ to $t-5$, Return $t-156$ to $t-53$, Turnover t-52 to t-1, Loaned Stocks, Market to Book, Size, Amihud Illiqudity, Breadth of Ownership, Institutional Ownership, Number of Analysts, Average Short Sale Duration, Average Lending Fee. Standard errors are two-way clustered at the firm and week level. T-statistics are below the parameter estimates in parenthesis. *** indicates significance at the $1 \%$ level, ** indicates significance at the $5 \%$ level, and * indicates significance at the $10 \%$ level.

Panel A: Interactions with Merger, Specialness and Momentum Crash

\begin{tabular}{|c|c|c|c|c|c|c|}
\hline & \multicolumn{6}{|c|}{ Closing } \\
\hline & (1) & (2) & (3) & (4) & (5) & (6) \\
\hline After Momentum Crash * SCGO I & $\begin{array}{c}0.0536^{* * *} \\
(4.18)\end{array}$ & & & & & \\
\hline After Momentum Crash * SCGO II & & $\begin{array}{c}0.0088 \\
(0.73)\end{array}$ & & & & \\
\hline Merger * SCGO I & & & $\begin{array}{c}-0.0254^{*} \\
(-1.95)\end{array}$ & & & \\
\hline Merger * SCGO II & & & & $\begin{array}{c}-0.0432^{* * *} \\
(-3.47)\end{array}$ & & \\
\hline Specialness * SCGO I & & & & & $\begin{array}{l}-0.0129 \\
(-1.36)\end{array}$ & \\
\hline Specialness * SCGO II & & & & & & $\begin{array}{c}-0.0114 \\
(-1.37)\end{array}$ \\
\hline SCGO I & $\begin{array}{c}0.0518^{* * *} \\
(5.19)\end{array}$ & & $\begin{array}{c}0.0589^{* * * *} \\
(5.97)\end{array}$ & & $\begin{array}{c}0.0617^{* * *} \\
(5.83)\end{array}$ & \\
\hline SCGO II & & $\begin{array}{c}0.0317^{* * *} \\
(3.27)\end{array}$ & & $\begin{array}{c}0.0328^{* * *} \\
(3.39)\end{array}$ & & $\begin{array}{c}0.0334^{* * *} \\
(3.26)\end{array}$ \\
\hline Merger & & & $\begin{array}{c}0.0121^{* * *} \\
(7.28)\end{array}$ & $\begin{array}{c}0.0123^{* * *} \\
(7.45)\end{array}$ & & \\
\hline Specialness & & & & & $\begin{array}{l}-0.0008 \\
(-0.31)\end{array}$ & $\begin{array}{c}0.0011 \\
(0.41)\end{array}$ \\
\hline Observations & 747119 & 716763 & 766355 & 734851 & 766355 & 734851 \\
\hline Adjusted $R^{2}$ & 0.21 & 0.21 & 0.21 & 0.21 & 0.21 & 0.21 \\
\hline Controls & Yes & Yes & Yes & Yes & Yes & Yes \\
\hline Week and Firm Fixed Effects & Yes & Yes & Yes & Yes & Yes & Yes \\
\hline
\end{tabular}


Panel B: Interactions with Size, Illiquidity and Institutional Ownership

\begin{tabular}{|c|c|c|c|c|c|c|}
\hline & \multicolumn{6}{|c|}{ Closing } \\
\hline & $(1)$ & $(2)$ & (3) & (4) & (5) & (6) \\
\hline Small Firm * SCGO I & $\begin{array}{c}-0.0611^{* * * *} \\
(-10.51)\end{array}$ & & & & & \\
\hline Small Firm * SCGO II & & $\begin{array}{c}-0.0503 * * * \\
(-10.29)\end{array}$ & & & & \\
\hline Illiquidity * SCGO I & & & $\begin{array}{c}-0.0816^{* * *} \\
(-14.34)\end{array}$ & & & \\
\hline Illiquidity * SCGO II & & & & $\begin{array}{c}-0.0721^{* * *} \\
(-14.97)\end{array}$ & & \\
\hline Low Instititutional Ownership * SCGO I & & & & & $\begin{array}{c}-0.0629 * * * \\
(-10.49)\end{array}$ & \\
\hline Low Instititutional Ownership * SCGO II & & & & & & $\begin{array}{c}-0.0575 * * * \\
(-11.33)\end{array}$ \\
\hline SCGO I & $\begin{array}{c}0.0994 * * * \\
(15.40)\end{array}$ & & $\begin{array}{c}0.1113 * * * \\
(17.42)\end{array}$ & & $\begin{array}{c}0.0918^{* * *} \\
(14.80)\end{array}$ & \\
\hline SCGO II & & $\begin{array}{c}0.0641 * * * \\
(11.95)\end{array}$ & & $\begin{array}{c}0.0775 * * * \\
(14.61)\end{array}$ & & $\begin{array}{c}0.0614 * * * \\
(11.97)\end{array}$ \\
\hline Small Firm & $\begin{array}{c}0.0005 \\
(0.28)\end{array}$ & $\begin{array}{r}0.0017 \\
(0.92)\end{array}$ & & & & \\
\hline Illiquidity & & & $\begin{array}{c}-0.0033^{*} \\
(-1.72)\end{array}$ & $\begin{array}{c}-0.0032 \\
(-1.62)\end{array}$ & & \\
\hline Low Instititutional Ownership & & & & & $\begin{array}{l}0.0000 \\
(0.02) \\
\end{array}$ & $\begin{array}{c}-0.0010 \\
(-0.48) \\
\end{array}$ \\
\hline Observations & 766355 & 734851 & 766355 & 734851 & 766355 & 734851 \\
\hline Adjusted $R^{2}$ & 0.21 & 0.21 & 0.21 & 0.21 & 0.21 & 0.21 \\
\hline Controls & Yes & Yes & Yes & Yes & Yes & Yes \\
\hline Week and Firm Fixed Effects & Yes & Yes & Yes & Yes & Yes & Yes \\
\hline
\end{tabular}




\section{Table 4: Are short sellers skilled in closing their positions?}

This table contains the results of weekly Fama-Macbeth Regressions that examine how the closing of short positions predicts future returns from August 2004 to June 2010, excluding the period of the short sale ban (September 15, 2008 to October 10, 2008). The dependent variable is the weekly stock return. Closing is the percentage of loaned shares that are returned to lenders during the week. $\mathrm{D}($ Closing) is a dummy variable equal to 1 if Closing for this stock is above the median in that week. Other variables are defined in Appendix 1. T-statistics are below the parameter estimates in parenthesis. $* * *$ indicates significance at the $1 \%$ level, $* *$ indicates significance at the $5 \%$ level, and * indicates significance at the $10 \%$ level.

\begin{tabular}{|c|c|c|c|c|}
\hline & \multicolumn{4}{|c|}{ Return } \\
\hline & (1) & (2) & (3) & (4) \\
\hline Closing (t-1) & $\begin{array}{c}0.0026^{* * *} \\
(3.48)\end{array}$ & $\begin{array}{c}0.0021^{* * *} \\
(3.15)\end{array}$ & & \\
\hline $\mathrm{D}$ (Closing) (t-1) & & & $\begin{array}{c}0.0010^{* * *} \\
(3.92)\end{array}$ & $\begin{array}{c}0.0007^{* * *} \\
(3.05)\end{array}$ \\
\hline Return t-4 to t-1 & $\begin{array}{c}-0.0474^{* * *} \\
(-4.97)\end{array}$ & $\begin{array}{c}-0.0571^{* * *} \\
(-6.15)\end{array}$ & $\begin{array}{c}-0.0524^{* * *} \\
(-5.62)\end{array}$ & $\begin{array}{c}-0.0571^{* * *} \\
(-6.33)\end{array}$ \\
\hline Return t-52 to $t-5$ & $\begin{array}{l}0.0600 \\
(1.30)\end{array}$ & $\begin{array}{c}0.0242 \\
(0.51)\end{array}$ & $\begin{array}{c}0.0606 \\
(1.36)\end{array}$ & $\begin{array}{c}0.0236 \\
(0.51)\end{array}$ \\
\hline Return t-156 to t-53 & $\begin{array}{c}0.1011^{* *} \\
(2.51)\end{array}$ & $\begin{array}{l}0.0484 \\
(1.29)\end{array}$ & $\begin{array}{c}0.0984^{* *} \\
(2.53)\end{array}$ & $\begin{array}{c}0.0450 \\
(1.21)\end{array}$ \\
\hline Turnover $\mathrm{t}-52$ to $\mathrm{t}-1$ & $\begin{array}{l}0.0036 \\
(0.37)\end{array}$ & $\begin{array}{l}0.0001 \\
(0.01)\end{array}$ & $\begin{array}{l}0.0025 \\
(0.24)\end{array}$ & $\begin{array}{c}-0.0022 \\
(-0.24)\end{array}$ \\
\hline Market to Book & & $\begin{array}{l}-0.0000 \\
(-0.27)\end{array}$ & & $\begin{array}{l}-0.0000 \\
(-0.04)\end{array}$ \\
\hline Size & & $\begin{array}{c}-0.0003 \\
(-0.97)\end{array}$ & & $\begin{array}{l}-0.0003 \\
(-0.99)\end{array}$ \\
\hline Amihud Illiqudity & & $\begin{array}{c}-0.0000^{* *} \\
(-2.06)\end{array}$ & & $\begin{array}{c}-0.0000^{* *} \\
(-2.41)\end{array}$ \\
\hline Breadth of Ownership & & $\begin{array}{c}-0.0025 \\
(-0.39)\end{array}$ & & $\begin{array}{l}-0.0032 \\
(-0.47)\end{array}$ \\
\hline Inst. Ownership & & $\begin{array}{l}0.0017 \\
(1.39)\end{array}$ & & $\begin{array}{l}0.0018 \\
(1.46)\end{array}$ \\
\hline Number of Analysts & & $\begin{array}{c}-0.0004^{* *} \\
(-2.13)\end{array}$ & & $\begin{array}{c}-0.0003^{*} \\
(-1.92)\end{array}$ \\
\hline Average Short Sale Duration & & $\begin{array}{r}-0.0000 \\
(-1.10)\end{array}$ & & $\begin{array}{c}-0.0000^{*} \\
(-1.67)\end{array}$ \\
\hline Average Lending Fee & & $\begin{array}{c}-0.0007^{* * *} \\
(-6.50)\end{array}$ & & $\begin{array}{c}-0.0006^{* * *} \\
(-6.45)\end{array}$ \\
\hline Constant & $\begin{array}{c}0.0001 \\
(0.08) \\
\end{array}$ & $\begin{array}{l}0.0096 \\
(1.39) \\
\end{array}$ & $\begin{array}{c}0.0000 \\
(0.00) \\
\end{array}$ & $\begin{array}{l}0.0099 \\
(1.43)\end{array}$ \\
\hline Observations & 951434 & 766373 & 1051599 & 808739 \\
\hline Average $R^{2}$ & 0.04 & 0.06 & 0.04 & 0.06 \\
\hline Fama-MacBeth & Yes & Yes & Yes & Yes \\
\hline
\end{tabular}




\section{Table 5: Does Short sellers’ Disposition Effect predict stock returns?}

This table contains the results of weekly Fama-MacBeth regressions that examine the effect of Short sale Capital Gains Overhang (SCGO) and Long Capital Gains Overhang (LCGO) on stock returns from August 2004 to June 2010, excluding the period of the short sale ban (September 15, 2008 to October 10, 2008). The dependent variable is the weekly return. The explanatory variables of interest are SCGO I and SCGO II as well as LCGO. Following Grinblatt and Han (2005), these variables are taken at the beginning of the prior week. Variables are defined in Appendix 1. T-statistics are below the parameter estimates in parenthesis. *** indicates significance at the $1 \%$ level, ** indicates significance at the $5 \%$ level, and * indicates significance at the $10 \%$ level.

\begin{tabular}{|c|c|c|c|c|c|c|}
\hline & \multicolumn{6}{|c|}{ Return } \\
\hline & $(1)$ & (2) & (3) & (4) & (5) & (6) \\
\hline LCGO (t-1) & $\begin{array}{c}0.0041^{* * *} \\
(4.13)\end{array}$ & $\begin{array}{c}0.0051^{* * *} \\
(4.92)\end{array}$ & & & & \\
\hline SCGO I (t-1) & & & $\begin{array}{c}-0.0093^{* * *} \\
(-4.09)\end{array}$ & $\begin{array}{c}-0.0070^{* * * *} \\
(-3.17)\end{array}$ & & \\
\hline SCGO II (t-1) & & & & & $\begin{array}{c}-0.0073^{* * *} \\
(-2.96)\end{array}$ & $\begin{array}{c}-0.0072^{* * *} \\
(-2.96)\end{array}$ \\
\hline Return $\mathrm{t}-4$ to $\mathrm{t}-1$ & $\begin{array}{c}-0.0604^{* * *} \\
(-6.34)\end{array}$ & $\begin{array}{c}-0.0654^{* * *} \\
(-7.05)\end{array}$ & $\begin{array}{c}-0.0631^{* * *} \\
(-6.91)\end{array}$ & $\begin{array}{c}-0.0669^{* * *} \\
(-7.42)\end{array}$ & $\begin{array}{c}-0.0583^{* * *} \\
(-5.78)\end{array}$ & $\begin{array}{c}-0.0665^{* * *} \\
(-6.71)\end{array}$ \\
\hline Return $\mathrm{t}-52$ to $\mathrm{t}-5$ & $\begin{array}{c}0.0030 \\
(0.06)\end{array}$ & $\begin{array}{c}-0.0409 \\
(-0.83)\end{array}$ & $\begin{array}{c}0.0317 \\
(0.72)\end{array}$ & $\begin{array}{c}0.0072 \\
(0.16)\end{array}$ & $\begin{array}{c}0.0490 \\
(1.09)\end{array}$ & $\begin{array}{l}0.0119 \\
(0.25)\end{array}$ \\
\hline Return t-156 to t-53 & $\begin{array}{c}0.0600 \\
(1.44)\end{array}$ & $\begin{array}{l}0.0016 \\
(0.04)\end{array}$ & $\begin{array}{c}0.0933^{* * *} \\
(2.39)\end{array}$ & $\begin{array}{l}0.0405 \\
(1.10)\end{array}$ & $\begin{array}{l}0.1107^{* * *} \\
(2.75)\end{array}$ & $\begin{array}{l}0.0467 \\
(1.25)\end{array}$ \\
\hline Turnover $\mathrm{t}-52$ to $\mathrm{t}-1$ & $\begin{array}{c}0.0003 \\
(0.04)\end{array}$ & $\begin{array}{c}-0.0071 \\
(-0.77)\end{array}$ & $\begin{array}{c}0.0039 \\
(0.41)\end{array}$ & $\begin{array}{l}-0.0027 \\
(-0.30)\end{array}$ & $\begin{array}{c}0.0028 \\
(0.30)\end{array}$ & $\begin{array}{c}-0.0026 \\
(-0.28)\end{array}$ \\
\hline Market to Book & & $\begin{array}{c}0.0000 \\
(0.31)\end{array}$ & & $\begin{array}{c}0.0000 \\
(0.03)\end{array}$ & & $\begin{array}{l}0.0000 \\
(0.29)\end{array}$ \\
\hline Size & & $\begin{array}{c}-0.0009^{* * *} \\
(-2.86)\end{array}$ & & $\begin{array}{l}-0.0005 \\
(-1.58)\end{array}$ & & $\begin{array}{c}-0.0005 \\
(-1.47)\end{array}$ \\
\hline Amihud Illiqudity & & $\begin{array}{c}-0.0001^{* * *} \\
(-3.61)\end{array}$ & & $\begin{array}{c}-0.0001^{* * *} \\
(-3.10)\end{array}$ & & $\begin{array}{c}-0.0001^{* * *} \\
(-2.92)\end{array}$ \\
\hline $\begin{array}{l}\text { Breadth of } \\
\text { Ownership }\end{array}$ & & 0.0029 & & -0.0018 & & -0.0020 \\
\hline & & $(0.43)$ & & $(-0.26)$ & & $(-0.31)$ \\
\hline Inst. Ownership & & $\begin{array}{c}0.0016 \\
(1.36)\end{array}$ & & $\begin{array}{c}0.0017 \\
(1.36)\end{array}$ & & $\begin{array}{c}0.0012 \\
(1.01)\end{array}$ \\
\hline Number of Analysts & & $\begin{array}{c}-0.0003 \\
(-1.59)\end{array}$ & & $\begin{array}{c}-0.0003^{*} \\
(-1.93)\end{array}$ & & $\begin{array}{c}-0.0003^{* *} \\
(-1.99)\end{array}$ \\
\hline $\begin{array}{l}\text { Average Short Sale } \\
\text { Duration }\end{array}$ & & $-0.0000^{* *}$ & & -0.0000 & & $-0.0000^{*}$ \\
\hline $\begin{array}{l}\text { Average Lending } \\
\text { Fee }\end{array}$ & & $\begin{array}{c}(-2.04) \\
-0.0005^{* * *} \\
(-6.24)\end{array}$ & & $\begin{array}{c}(-1.57) \\
-0.0005^{* * *} \\
(-5.88)\end{array}$ & & $\begin{array}{c}(-1.76) \\
-0.0006^{* * *} \\
(-6.48)\end{array}$ \\
\hline Constant & $\begin{array}{c}0.0009 \\
(0.89) \\
\end{array}$ & $\begin{array}{c}0.0238^{* * *} \\
(3.43)\end{array}$ & $\begin{array}{c}0.0007 \\
(0.63) \\
\end{array}$ & $\begin{array}{c}0.0149^{* * *} \\
(2.14)\end{array}$ & $\begin{array}{l}0.0007 \\
(0.70) \\
\end{array}$ & $\begin{array}{c}0.0142^{* *} \\
(1.99)\end{array}$ \\
\hline Observations & 1062070 & 817084 & 1003466 & 803654 & 961621 & 771276 \\
\hline Average $\mathrm{R}^{2}$ & 0.04 & 0.06 & 0.04 & 0.06 & 0.04 & 0.06 \\
\hline Fama-MacBeth & Yes & Yes & Yes & Yes & Yes & Yes \\
\hline
\end{tabular}




\section{Table 6: Horse-Race: SCGO vs. LCGO}

This table contains the results of weekly Fama-MacBeth regressions that examine the effect of Short sale Capital Gains Overhang (SCGO) and Long Capital Gains Overhang (LCGO) on stock returns from August 2004 to June 2010, excluding the period of the short sale ban (September 15, 2008 to October 10, 2008). The dependent variable is the weekly return. The explanatory variables of interest are SCGO and LCGO. Both variables are taken at the beginning of the prior week. Variables are defined in Appendix 1. T-statistics are below the parameter estimates in parenthesis. $* * *$ indicates significance at the $1 \%$ level, $* *$ indicates significance at the $5 \%$ level, and * indicates significance at the $10 \%$ level.

\begin{tabular}{|c|c|c|c|c|}
\hline & \multicolumn{4}{|c|}{ Return } \\
\hline & (1) & (2) & (3) & (4) \\
\hline SCGO I (t-1) & $\begin{array}{c}-0.0076^{* * *} \\
(-3.52)\end{array}$ & $\begin{array}{c}-0.0048^{* *} \\
(-2.33)\end{array}$ & & \\
\hline SCGO II (t-1) & & & $\begin{array}{c}-0.0053^{* *} \\
(-2.18)\end{array}$ & $\begin{array}{c}-0.0050^{* *} \\
(-2.14)\end{array}$ \\
\hline LCGO (t-1) & $\begin{array}{c}0.0029^{* * *} \\
(3.06)\end{array}$ & $\begin{array}{c}0.0042^{* * * *} \\
(4.36)\end{array}$ & $\begin{array}{c}0.0037^{* * *} \\
(3.61)\end{array}$ & $\begin{array}{c}0.0043^{* * * *} \\
(4.34)\end{array}$ \\
\hline Return $\mathrm{t}-4$ to $\mathrm{t}-1$ & $\begin{array}{c}-0.0663^{* * *} \\
(-7.09)\end{array}$ & $\begin{array}{c}-0.0702^{* * *} \\
(-7.59)\end{array}$ & $\begin{array}{c}-0.0623^{* * *} \\
(-6.11)\end{array}$ & $\begin{array}{c}-0.0697^{* * *} \\
(-6.94)\end{array}$ \\
\hline Return t-52 to t-5 & $\begin{array}{c}-0.0050 \\
(-0.11)\end{array}$ & $\begin{array}{c}-0.0419 \\
(-0.85)\end{array}$ & $\begin{array}{l}0.0008 \\
(0.02)\end{array}$ & $\begin{array}{l}-0.0413 \\
(-0.82)\end{array}$ \\
\hline Return t-156 to t-53 & $\begin{array}{l}0.0670 \\
(1.61)\end{array}$ & $\begin{array}{l}0.0071 \\
(0.18)\end{array}$ & $\begin{array}{c}0.0764^{*} \\
(1.78)\end{array}$ & $\begin{array}{l}0.0128 \\
(0.32)\end{array}$ \\
\hline Turnover $\mathrm{t}-52$ to $\mathrm{t}-1$ & $\begin{array}{l}0.0020 \\
(0.22)\end{array}$ & $\begin{array}{c}-0.0065 \\
(-0.71)\end{array}$ & $\begin{array}{c}-0.0002 \\
(-0.02)\end{array}$ & $\begin{array}{c}-0.0070 \\
(-0.76)\end{array}$ \\
\hline Market to Book & & $\begin{array}{l}0.0000 \\
(0.34)\end{array}$ & & $\begin{array}{l}0.0000 \\
(0.60)\end{array}$ \\
\hline Size & & $\begin{array}{c}-0.0010^{* * *} \\
(-2.98)\end{array}$ & & $\begin{array}{c}-0.0009^{* * *} \\
(-2.84)\end{array}$ \\
\hline Amihud Illiqudity & & $\begin{array}{c}-0.0001^{* * *} \\
(-3.94)\end{array}$ & & $\begin{array}{c}-0.0001^{* * *} \\
(-3.69)\end{array}$ \\
\hline Breadth of Ownership & & $\begin{array}{l}0.0027 \\
(0.41)\end{array}$ & & $\begin{array}{l}0.0026 \\
(0.40)\end{array}$ \\
\hline Inst. Ownership & & $\begin{array}{l}0.0016 \\
(1.33)\end{array}$ & & $\begin{array}{l}0.0012 \\
(0.98)\end{array}$ \\
\hline Number of Analysts & & $\begin{array}{c}-0.0003 \\
(-1.64)\end{array}$ & & $\begin{array}{c}-0.0003^{*} \\
(-1.68)\end{array}$ \\
\hline Average Short Sale Duration & & $\begin{array}{c}-0.0000^{*} \\
(-1.71)\end{array}$ & & $\begin{array}{c}-0.0000^{*} \\
(-1.83)\end{array}$ \\
\hline Average Lending Fee & & $\begin{array}{c}-0.0005^{* * *} \\
(-5.87)\end{array}$ & & $\begin{array}{c}-0.0006^{* * *} \\
(-6.33)\end{array}$ \\
\hline Constant & $\begin{array}{c}0.0008 \\
(0.76) \\
\end{array}$ & $\begin{array}{c}0.0249^{* * * *} \\
(3.54) \\
\end{array}$ & $\begin{array}{c}0.0010 \\
(0.90) \\
\end{array}$ & $\begin{array}{c}0.0242^{* * *} \\
(3.37) \\
\end{array}$ \\
\hline Observations & 1003465 & 803653 & 961621 & 771276 \\
\hline Average $\mathrm{R}^{2}$ & 0.04 & 0.06 & 0.04 & 0.06 \\
\hline Fama-MacBeth & Yes & Yes & Yes & Yes \\
\hline
\end{tabular}




\section{Table 7: Portfolio Analysis}

This table contains the results of weekly portfolio analysis from August 2004 to June 2010, excluding the period of the short sale ban (September 15, 2008 to October 10, 2008). At the beginning of each week, stocks are sorted simultaneously into 4 quartiles on cumulative returns over the prior 12 weeks (R1=losers, R4=winners) and by a measure of short sale capital gains overhang in the prior week (SCGO $1=$ low capital gains SCGO 4 = high capital gains). On the basis of these quartiles, we form 16 equal weighted portfolios at the beginning of each week. On the left half of the panel we report average weekly returns in percent of the portfolios, on the right half we report weekly 3 Factor Alphas controlling for the Fama French (1993) factors. T-statistics are computed along the time-series and reported below the parameter estimates in parenthesis. *** indicates significance at the $1 \%$ level, ** indicates significance at the $5 \%$ level, and * indicates significance at the $10 \%$ level.

Panel A: Short Sale Capital Gains I- Excluding January

\begin{tabular}{|c|c|c|c|c|c|c|c|c|}
\hline & \multicolumn{4}{|c|}{ Returns } & \multicolumn{4}{|c|}{3 Factor Alphas } \\
\hline & R1 (low) & R2 & R3 & R4 (high) & R1 (low) & R2 & R3 & R4 (high) \\
\hline $\begin{array}{l}\text { SCGO_I } 1 \\
\text { (low) }\end{array}$ & $\begin{array}{l}0.571^{* *} \\
(2.24)\end{array}$ & $\begin{array}{l}0.337^{*} \\
(1.70)\end{array}$ & $\begin{array}{l}0.275 \\
(1.63)\end{array}$ & $\begin{array}{l}0.284 \\
(1.53)\end{array}$ & $\begin{array}{l}0.222^{*} \\
(1.82)\end{array}$ & $\begin{array}{l}0.038 \\
(0.54)\end{array}$ & $\begin{array}{l}0.009 \\
(0.20)\end{array}$ & $\begin{array}{l}0.007 \\
(0.11)\end{array}$ \\
\hline SCGO_I 2 & $\begin{array}{l}0.427^{*} \\
(1.78)\end{array}$ & $\begin{array}{l}0.333^{*} \\
(1.88)\end{array}$ & $\begin{array}{l}0.208 \\
(1.30)\end{array}$ & $\begin{array}{l}0.202 \\
(1.18)\end{array}$ & $\begin{array}{l}0.083 \\
(0.79)\end{array}$ & $\begin{array}{l}0.051 \\
(1.15)\end{array}$ & $\begin{array}{l}-0.055^{*} \\
(-1.93)\end{array}$ & $\begin{array}{l}-0.065 \\
(-1.22)\end{array}$ \\
\hline SCGO_I 3 & $\begin{array}{l}0.454^{*} \\
(1.90)\end{array}$ & $\begin{array}{l}0.284 \\
(1.52)\end{array}$ & $\begin{array}{l}0.206 \\
(1.19)\end{array}$ & $\begin{array}{l}0.131 \\
(0.68)\end{array}$ & $\begin{array}{l}0.108 \\
(1.13)\end{array}$ & $\begin{array}{l}-0.010 \\
(-0.20)\end{array}$ & $\begin{array}{l}-0.070^{*} \\
(-1.67)\end{array}$ & $\begin{array}{c}-0.154^{* *} \\
(-2.02)\end{array}$ \\
\hline $\begin{array}{l}\text { SCGO_I } 4 \\
\text { (high) }\end{array}$ & $\begin{array}{l}0.505^{*} \\
(1.78)\end{array}$ & $\begin{array}{l}0.088 \\
(0.42)\end{array}$ & $\begin{array}{l}0.006 \\
(0.03)\end{array}$ & $\begin{array}{l}-0.152 \\
(-0.61)\end{array}$ & $\begin{array}{l}0.102 \\
(0.97)\end{array}$ & $\begin{array}{c}-0.231^{* * *} \\
(-3.78)\end{array}$ & $\begin{array}{c}-0.298^{* * *} \\
(-3.83)\end{array}$ & $\begin{array}{c}-0.463^{* * *} \\
(-3.05)\end{array}$ \\
\hline $\begin{array}{l}\text { SCGO_I } 4 \text { - } \\
\text { SCGO_I } 1\end{array}$ & $\begin{array}{l}-0.067 \\
(-0.55)\end{array}$ & $\begin{array}{c}-0.250^{* * *} \\
(-2.82)\end{array}$ & $\begin{array}{c}-0.268^{* * *} \\
(-2.83)\end{array}$ & $\begin{array}{c}-0.436^{* * *} \\
(-2.99)\end{array}$ & $\begin{array}{l}-0.120 \\
(-1.05)\end{array}$ & $\begin{array}{c}-0.269^{* * *} \\
(-3.09)\end{array}$ & $\begin{array}{c}-0.308^{* * *} \\
(-3.38)\end{array}$ & $\begin{array}{c}-0.470^{* * *} \\
(-3.29)\end{array}$ \\
\hline
\end{tabular}

Panel B: Short Sale Capital Gains I - Entire Year

\begin{tabular}{|c|c|c|c|c|c|c|c|c|}
\hline & \multicolumn{4}{|c|}{ Returns } & \multicolumn{4}{|c|}{3 Factor Alphas } \\
\hline & R1 (low) & R2 & R3 & R4 (high) & R1 (low) & $\mathrm{R} 2$ & R3 & R4 (high) \\
\hline SCGO_I 1 & $0.533^{* *}$ & 0.298 & 0.221 & 0.212 & $0.240^{* *}$ & 0.042 & -0.011 & -0.035 \\
\hline (low) & $(2.22)$ & (1.58) & (1.38) & (1.20) & $(2.01)$ & $(0.62)$ & $(-0.26)$ & $(-0.55)$ \\
\hline \multirow[t]{2}{*}{ SCGO_I 2} & $0.409^{*}$ & $0.299^{*}$ & 0.170 & 0.171 & 0.126 & 0.059 & $-0.056^{* *}$ & -0.063 \\
\hline & (1.82) & (1.79) & (1.12) & (1.05) & (1.26) & (1.41) & $(-2.04)$ & $(-1.25)$ \\
\hline \multirow[t]{2}{*}{ SCGO_I 3} & $0.408^{*}$ & 0.267 & 0.191 & 0.128 & 0.121 & 0.017 & -0.048 & $-0.122^{*}$ \\
\hline & (1.83) & (1.51) & $(1.15)$ & $(0.70)$ & (1.36) & $(0.38)$ & $(-1.21)$ & $(-1.71)$ \\
\hline SCGO_I 4 & $0.496^{*}$ & 0.109 & 0.032 & -0.068 & 0.158 & $-0.167^{* * * *}$ & $-0.234^{* * * *}$ & $-0.342^{* *}$ \\
\hline (high) & $(1.86)$ & $(0.54)$ & $(0.16)$ & $(-0.29)$ & (1.52) & $(-2.74)$ & $(-3.05)$ & $(-2.37)$ \\
\hline SCGO_I 4 - & -0.036 & $-0.189^{* *}$ & $-0.189^{* *}$ & $-0.280^{* *}$ & -0.082 & $-0.209^{* *}$ & $-0.223^{* *}$ & $-0.307^{* *}$ \\
\hline SCGO_I 1 & $(-0.32)$ & $(-2.17)$ & $(-2.02)$ & $(-1.97)$ & $(-0.76)$ & $(-2.44)$ & $(-2.48)$ & $(-2.20)$ \\
\hline
\end{tabular}

Panel C: Short Sale Capital Gains II - Excluding January

\begin{tabular}{|c|c|c|c|c|c|c|c|c|}
\hline & \multicolumn{4}{|c|}{ Returns } & \multicolumn{4}{|c|}{3 Factor Alphas } \\
\hline & R1 (low) & $\mathrm{R} 2$ & R3 & R4 (high) & R1 (low) & $\mathrm{R} 2$ & $\mathrm{R} 3$ & R4 (high) \\
\hline SCGO_I 1 & 0.413 & $0.369^{*}$ & 0.248 & 0.304 & 0.045 & 0.064 & -0.032 & 0.022 \\
\hline (low) & (1.53) & $(1.80)$ & (1.39) & (1.62) & $(0.35)$ & $(0.85)$ & $(-0.63)$ & $(0.34)$ \\
\hline \multirow[t]{2}{*}{ SCGO_I 2} & $0.512^{* *}$ & $0.340^{*}$ & 0.241 & 0.219 & $0.166^{*}$ & 0.046 & -0.026 & -0.055 \\
\hline & (2.14) & $(1.82)$ & $(1.47)$ & (1.23) & (1.71) & $(0.96)$ & $(-0.97)$ & $(-1.00)$ \\
\hline \multirow[t]{2}{*}{ SCGO_I 3} & $0.433^{*}$ & 0.297 & 0.179 & 0.186 & 0.077 & 0.004 & $-0.097^{* *}$ & -0.103 \\
\hline & (1.79) & (1.60) & (1.03) & (0.97) & $(0.87)$ & (0.09) & $(-2.50)$ & $(-1.55)$ \\
\hline SCGO_I 4 & $0.507^{*}$ & 0.095 & 0.067 & -0.034 & 0.108 & $-0.227^{* * *}$ & $-0.243^{* * *}$ & $-0.361^{* * *}$ \\
\hline (high) & (1.79) & $(0.45)$ & $(0.32)$ & $(-0.14)$ & $(0.99)$ & $(-3.81)$ & $(-3.46)$ & $(-2.86)$ \\
\hline SCGO_I 4 - & 0.094 & $-0.275^{* * * *}$ & $-0.181^{*}$ & $-0.339^{* * *}$ & 0.064 & $-0.291^{* * * *}$ & $-0.211^{* *}$ & $-0.383^{* * * *}$ \\
\hline SCGO_I 1 & $(0.79)$ & $(-2.85)$ & $(-1.93)$ & $(-2.68)$ & $(0.54)$ & $(-3.02)$ & $(-2.30)$ & $(-3.12)$ \\
\hline
\end{tabular}


Panel D: Short Sale Capital Gains II - Entire Year

\begin{tabular}{|c|c|c|c|c|c|c|c|c|}
\hline & \multicolumn{4}{|c|}{ Returns } & \multicolumn{4}{|c|}{3 Factor Alphas } \\
\hline & R1 (low) & $\mathrm{R} 2$ & R3 & R4 (high) & R1 (low) & $\mathrm{R} 2$ & R3 & R4 (high) \\
\hline SCGO_I 1 & 0.375 & 0.314 & 0.184 & 0.227 & 0.063 & $\begin{array}{l}0.049 \\
0.70)\end{array}$ & $\begin{array}{l}-0.061 \\
(-125)\end{array}$ & -0.024 \\
\hline $\begin{array}{l}\text { (low) } \\
\text { SCGO I2 }\end{array}$ & $\begin{array}{l}(1.47) \\
0.459^{* *}\end{array}$ & $\begin{array}{l}(1.60) \\
0.302^{*}\end{array}$ & $\begin{array}{l}(1.07) \\
0203\end{array}$ & (1.26) & (0.53) & $(0.70)$ & $\begin{array}{l}(-1.25) \\
-0.026\end{array}$ & \\
\hline SCGO_I 2 & $\begin{array}{c}0.459^{* *} \\
(2.04)\end{array}$ & $\begin{array}{l}0.302^{*} \\
(1.71)\end{array}$ & $\begin{array}{l}0.203 \\
(1.31)\end{array}$ & $\begin{array}{l}0.177 \\
(1.05)\end{array}$ & $\begin{array}{l}0.169^{*} \\
(1.86)\end{array}$ & $\begin{array}{l}0.053 \\
(1.16)\end{array}$ & $\begin{array}{l}-0.026 \\
(-1.00)\end{array}$ & $\begin{array}{l}-0.064 \\
(-1.24)\end{array}$ \\
\hline SCGO_I 3 & $\begin{array}{l}0.393^{*} \\
(1.72)\end{array}$ & $\begin{array}{l}0.280 \\
(1.59)\end{array}$ & $\begin{array}{l}0.166 \\
(1.01)\end{array}$ & $\begin{array}{l}0.189 \\
(1.03)\end{array}$ & $\begin{array}{l}0.098 \\
(1.15)\end{array}$ & $\begin{array}{l}0.031 \\
(0.70)\end{array}$ & $\begin{array}{c}-0.073^{* *} \\
(-1.97)\end{array}$ & $\begin{array}{l}-0.065 \\
(-1.01)\end{array}$ \\
\hline $\begin{array}{l}\text { SCGO_I } 4 \\
\text { (high) }\end{array}$ & $\begin{array}{l}0.507^{*} \\
(1.90)\end{array}$ & $\begin{array}{l}0.128 \\
(0.64)\end{array}$ & $\begin{array}{l}0.063 \\
(0.32)\end{array}$ & $\begin{array}{l}0.020 \\
(0.09)\end{array}$ & $\begin{array}{l}0.171 \\
(1.61)\end{array}$ & $\begin{array}{c}-0.148^{* * *} \\
(-2.51)\end{array}$ & $\begin{array}{c}-0.208^{* * * *} \\
(-3.07)\end{array}$ & $\begin{array}{c}-0.263^{* *} \\
(-2.19)\end{array}$ \\
\hline $\begin{array}{l}\text { SCGO_I } 4 \text { - } \\
\text { SCGO_I } 1\end{array}$ & $\begin{array}{l}0.132 \\
(1.19)\end{array}$ & $\begin{array}{c}-0.186^{* *} \\
(-1.98)\end{array}$ & $\begin{array}{l}-0.121 \\
(-1.32)\end{array}$ & $\begin{array}{l}-0.207^{*} \\
(-1.70)\end{array}$ & $\begin{array}{l}0.108 \\
(0.98)\end{array}$ & $\begin{array}{c}-0.197^{* *} \\
(-2.11)\end{array}$ & $\begin{array}{l}-0.147 \\
(-1.65)\end{array}$ & $\begin{array}{c}0.239^{* *} \\
(-2.02)\end{array}$ \\
\hline
\end{tabular}




\section{Table 8: Robustness check: Different Return controls}

This table contains robustness checks for Table 2, Table 5 and Table 6 . In the robustness check, we replace the prior year return control with individual controls for each quarter. Panel A corresponds to Regression 2, 4, 5 and 6 from Table 2. Panel B corresponds to regressions 4 and 6 of Table 4 and regressions 2 and 4 of Table 5. Variables are defined in Appendix 1. Fama-Macbeth regressions are at weekly frequency. In the OLS regressions, standard errors are two-way clustered at the firm and week level. We report average $\mathrm{R}^{2}$ for the Fama-Macbeth regression and adjusted $\mathrm{R}^{2}$ for the OLS regressions. T-statistics are below the parameter estimates in parenthesis. *** indicates significance at the $1 \%$ level, ** indicates significance at the $5 \%$ level, and * indicates significance at the $10 \%$ level.

Panel A: Short sale Capital Gains and Closing of Short Postitions (robustness to Table 2)

\begin{tabular}{|c|c|c|c|c|}
\hline & \multicolumn{4}{|c|}{ Closing } \\
\hline & (1) & (2) & (3) & (4) \\
\hline SCGO I & $\begin{array}{c}0.0908^{* * * *} \\
(7.21)\end{array}$ & $\begin{array}{c}0.0851^{* * *} \\
(13.10)\end{array}$ & & \\
\hline SCGO II & & & $\begin{array}{l}0.0511^{* * *} \\
(4.36)\end{array}$ & $\begin{array}{c}0.0426^{* * *} \\
(8.69)\end{array}$ \\
\hline Return $\mathrm{t}-4$ to $\mathrm{t}-1$ & $\begin{array}{c}0.4198^{* * *} \\
(11.83)\end{array}$ & $\begin{array}{c}0.3838^{* * *} \\
(17.86)\end{array}$ & $\begin{array}{c}0.3602^{* * *} \\
(9.59)\end{array}$ & $\begin{array}{c}0.3027^{* * *} \\
(14.36)\end{array}$ \\
\hline Return t-12 to t-5 & $\begin{array}{c}0.4794^{* * * *} \\
(13.86)\end{array}$ & $\begin{array}{c}0.4257^{* * * *} \\
(15.30)\end{array}$ & $\begin{array}{c}0.3811^{* * * *} \\
(12.84)\end{array}$ & $\begin{array}{c}0.3393^{* * *} \\
(12.68)\end{array}$ \\
\hline Return $\mathrm{t}-26$ to $\mathrm{t}-13$ & $\begin{array}{l}0.4815^{* * *} \\
(16.95)\end{array}$ & $\begin{array}{c}0.4577^{* * *} \\
(12.45)\end{array}$ & $\begin{array}{l}0.4205^{* * *} \\
(16.19)\end{array}$ & $\begin{array}{c}0.4145^{* * *} \\
(11.20)\end{array}$ \\
\hline Return $\mathrm{t}-39$ to $\mathrm{t}-27$ & $\begin{array}{c}0.2736^{* * * *} \\
(11.83)\end{array}$ & $\begin{array}{c}0.2802^{* * * *} \\
(8.55)\end{array}$ & $\begin{array}{c}0.2700^{* * *} \\
(11.81)\end{array}$ & $\begin{array}{c}0.2820^{* * * *} \\
(8.46)\end{array}$ \\
\hline Return $t-52$ to $t-40$ & $\begin{array}{c}0.1371^{* * * *} \\
(6.29)\end{array}$ & $\begin{array}{c}0.1868^{* * * *} \\
(6.32)\end{array}$ & $\begin{array}{c}0.1385^{* * * *} \\
(6.41)\end{array}$ & $\begin{array}{c}0.1925^{* * *} \\
(6.38)\end{array}$ \\
\hline Return t-156 to t-53 & $\begin{array}{c}0.3900^{* * * *} \\
(6.66)\end{array}$ & $\begin{array}{c}0.4532^{* * * *} \\
(2.95)\end{array}$ & $\begin{array}{c}0.4039^{* * *} \\
(6.76)\end{array}$ & $\begin{array}{c}0.4805^{* * *} \\
(3.07)\end{array}$ \\
\hline Turnover t-52 to t-1 & $\begin{array}{c}0.3241^{* * *} \\
(24.13)\end{array}$ & $\begin{array}{c}0.1132^{* * *} \\
(3.78)\end{array}$ & $\begin{array}{c}0.3501^{* * *} \\
(25.40)\end{array}$ & $\begin{array}{c}0.1247^{* * *} \\
(4.09)\end{array}$ \\
\hline Loaned Stocks & $\begin{array}{l}-0.0083^{* * *} \\
(-46.41)\end{array}$ & $\begin{array}{l}-0.0060^{* * *} \\
(-36.86)\end{array}$ & $\begin{array}{l}-0.0086^{* * *} \\
(-48.87)\end{array}$ & $\begin{array}{c}-0.0060^{* * * *} \\
(-36.27)\end{array}$ \\
\hline Market to Book & $\begin{array}{c}-0.0008^{* * *} \\
(-9.60)\end{array}$ & $\begin{array}{c}0.0002 \\
(0.54)\end{array}$ & $\begin{array}{c}-0.0008^{* * *} \\
(-8.98)\end{array}$ & $\begin{array}{c}0.0002 \\
(0.46)\end{array}$ \\
\hline Size & $\begin{array}{c}-0.0089^{* * *} \\
(-9.99)\end{array}$ & $\begin{array}{c}-0.0072^{* * * *} \\
(-2.74)\end{array}$ & $\begin{array}{c}-0.0091^{* * *} \\
(-9.92)\end{array}$ & $\begin{array}{c}-0.0080^{* * *} \\
(-2.94)\end{array}$ \\
\hline Amihud Illiqudity & $\begin{array}{c}0.0001 \\
(0.85)\end{array}$ & $\begin{array}{c}0.0004^{* * *} \\
(3.35)\end{array}$ & $\begin{array}{c}0.0001 \\
(0.92)\end{array}$ & $\begin{array}{c}0.0003^{* * *} \\
(3.06)\end{array}$ \\
\hline Breadth of Ownership & $\begin{array}{c}0.4041^{* * * *} \\
(24.10)\end{array}$ & $\begin{array}{c}0.2042^{* * * *} \\
(3.64)\end{array}$ & $\begin{array}{c}0.4051^{* * *} \\
(24.47)\end{array}$ & $\begin{array}{c}0.2116^{* * *} \\
(3.72)\end{array}$ \\
\hline Inst. Ownership & $\begin{array}{l}0.0425^{* * *} \\
(8.93)\end{array}$ & $\begin{array}{l}0.0309^{* * *} \\
(5.74)\end{array}$ & $\begin{array}{l}0.0410^{* * *} \\
(8.77)\end{array}$ & $\begin{array}{c}0.0257^{* * *} \\
(4.63)\end{array}$ \\
\hline Number of Analysts & $\begin{array}{c}-0.0032^{* * *} \\
(-5.85)\end{array}$ & $\begin{array}{c}-0.0060^{* * * *} \\
(-5.91)\end{array}$ & $\begin{array}{c}-0.0033^{* * *} \\
(-5.88)\end{array}$ & $\begin{array}{c}-0.0064^{* * *} \\
(-6.17)\end{array}$ \\
\hline Average Short Sale Duration & $\begin{array}{c}-0.0007^{* * *} \\
(-51.61)\end{array}$ & $\begin{array}{c}-0.0006^{* * * *} \\
(-48.32)\end{array}$ & $\begin{array}{c}-0.0007^{* * *} \\
(-53.72)\end{array}$ & $\begin{array}{c}-0.0006^{* * *} \\
(-46.01)\end{array}$ \\
\hline Average Lending Fee & $\begin{array}{c}0.0014^{* *} \\
(2.44)\end{array}$ & $\begin{array}{c}0.0031^{* * * *} \\
(5.47)\end{array}$ & $\begin{array}{c}0.0022^{* * * *} \\
(3.80)\end{array}$ & $\begin{array}{c}0.0037^{* * * *} \\
(6.36)\end{array}$ \\
\hline $\begin{array}{l}\text { Observations } \\
\text { Average } R^{2} / \text { Adjusted } R^{2}\end{array}$ & $\begin{array}{c}766240 \\
0.15\end{array}$ & $\begin{array}{c}766240 \\
0.21\end{array}$ & $\begin{array}{l}734851 \\
0.15\end{array}$ & $\begin{array}{c}734851 \\
0.21\end{array}$ \\
\hline Fama-MacBeth & Yes & Yes & No & No \\
\hline Firm and Week F.E. & No & No & Yes & Yes \\
\hline
\end{tabular}


Panel B: Short Sale Capital Gains and Returns (robustness to Table 5 and Table 6)

\begin{tabular}{|c|c|c|c|c|}
\hline & \multicolumn{4}{|c|}{ Return } \\
\hline & $(1)$ & $(2)$ & (3) & $(4)$ \\
\hline SCGO I (t-1) & $\begin{array}{c}-0.0085^{* * *} \\
(-3.94)\end{array}$ & $\begin{array}{c}-0.0066^{* * *} \\
(-3.23)\end{array}$ & & \\
\hline SCGO II (t-1) & & & $\begin{array}{c}-0.0087^{* * *} \\
(-3.65)\end{array}$ & $\begin{array}{c}-0.0068^{* * *} \\
(-2.91)\end{array}$ \\
\hline LCGO (t-1) & & $\begin{array}{c}0.0044^{* * *} \\
(4.61)\end{array}$ & & $\begin{array}{c}0.0046^{* * *} \\
(4.54)\end{array}$ \\
\hline Return $\mathrm{t}-4$ to $\mathrm{t}-1$ & $\begin{array}{c}-0.0709^{* * *} \\
(-7.53)\end{array}$ & $\begin{array}{c}-0.0753^{* * *} \\
(-7.68)\end{array}$ & $\begin{array}{c}-0.0705^{* * *} \\
(-6.90)\end{array}$ & $\begin{array}{c}-0.0748^{* * *} \\
(-7.11)\end{array}$ \\
\hline Return $\mathrm{t}-12$ to $\mathrm{t}-5$ & $\begin{array}{c}-0.0181 \\
(-1.35)\end{array}$ & $\begin{array}{c}-0.0316^{* *} \\
(-2.20)\end{array}$ & $\begin{array}{c}-0.0145 \\
(-1.10)\end{array}$ & $\begin{array}{c}-0.0290^{* *} \\
(-2.03)\end{array}$ \\
\hline Return t-26 to t-13 & $\begin{array}{l}0.0167 \\
(0.98)\end{array}$ & $\begin{array}{c}-0.0011 \\
(-0.06)\end{array}$ & $\begin{array}{c}0.0212 \\
(1.24)\end{array}$ & $\begin{array}{c}0.0012 \\
(0.07)\end{array}$ \\
\hline Return t-39 to t-27 & $\begin{array}{c}0.0116 \\
(0.84)\end{array}$ & $\begin{array}{c}-0.0006 \\
(-0.04)\end{array}$ & $\begin{array}{l}0.0107 \\
(0.76)\end{array}$ & $\begin{array}{c}-0.0019 \\
(-0.12)\end{array}$ \\
\hline Return $\mathrm{t}-52$ to $\mathrm{t}-40$ & $\begin{array}{c}-0.0031 \\
(-0.26)\end{array}$ & $\begin{array}{c}-0.0121 \\
(-0.97)\end{array}$ & $\begin{array}{c}-0.0018 \\
(-0.14)\end{array}$ & $\begin{array}{c}-0.0108 \\
(-0.83)\end{array}$ \\
\hline Return t-156 to t-53 & $\begin{array}{c}0.0453 \\
(1.30)\end{array}$ & $\begin{array}{c}0.0109 \\
(0.29)\end{array}$ & $\begin{array}{c}0.0519 \\
(1.47)\end{array}$ & $\begin{array}{c}0.0169 \\
(0.45)\end{array}$ \\
\hline Turnover $\mathrm{t}-52$ to $\mathrm{t}-1$ & $\begin{array}{c}-0.0045 \\
(-0.53)\end{array}$ & $\begin{array}{c}-0.0086 \\
(-1.00)\end{array}$ & $\begin{array}{c}-0.0044 \\
(-0.51)\end{array}$ & $\begin{array}{c}-0.0090 \\
(-1.04)\end{array}$ \\
\hline Market to Book & $\begin{array}{c}-0.0000 \\
(-0.28)\end{array}$ & $\begin{array}{c}-0.0000 \\
(-0.02)\end{array}$ & $\begin{array}{c}0.0000 \\
(0.00)\end{array}$ & $\begin{array}{c}0.0000 \\
(0.26)\end{array}$ \\
\hline Size & $\begin{array}{c}-0.0004 \\
(-1.26)\end{array}$ & $\begin{array}{c}-0.0008^{* * *} \\
(-2.59)\end{array}$ & $\begin{array}{c}-0.0004 \\
(-1.24)\end{array}$ & $\begin{array}{c}-0.0008^{* *} \\
(-2.53)\end{array}$ \\
\hline Amihud Illiqudity & $\begin{array}{c}-0.0001^{* * * *} \\
(-3.05)\end{array}$ & $\begin{array}{c}-0.0001^{* * *} \\
(-3.83)\end{array}$ & $\begin{array}{c}-0.0001^{* * * *} \\
(-3.05)\end{array}$ & $\begin{array}{c}-0.0001^{* * *} \\
(-3.73)\end{array}$ \\
\hline Breadth of Ownership & $\begin{array}{c}-0.0024 \\
(-0.36)\end{array}$ & $\begin{array}{c}0.0018 \\
(0.27)\end{array}$ & $\begin{array}{c}-0.0025 \\
(-0.38)\end{array}$ & $\begin{array}{c}0.0017 \\
(0.27)\end{array}$ \\
\hline Inst. Ownership & $\begin{array}{c}0.0016 \\
(1.34)\end{array}$ & $\begin{array}{l}0.0016 \\
(1.36)\end{array}$ & $\begin{array}{c}0.0011 \\
(0.93)\end{array}$ & $\begin{array}{c}0.0012 \\
(0.97)\end{array}$ \\
\hline Number of Analysts & $\begin{array}{r}-0.0003^{*} \\
(-1.80)\end{array}$ & $\begin{array}{c}-0.0003 \\
(-1.47)\end{array}$ & $\begin{array}{c}-0.0003^{*} \\
(-1.91)\end{array}$ & $\begin{array}{c}-0.0003 \\
(-1.57)\end{array}$ \\
\hline Average Short Sale Duration & $\begin{array}{c}-0.0000 \\
(-1.33)\end{array}$ & $\begin{array}{c}-0.0000 \\
(-1.44)\end{array}$ & $\begin{array}{c}-0.0000 \\
(-1.58)\end{array}$ & $\begin{array}{c}-0.0000 \\
(-1.62)\end{array}$ \\
\hline Average Lending Fee & $\begin{array}{c}-0.0005^{* * *} \\
(-5.90)\end{array}$ & $\begin{array}{c}-0.0005^{* * *} \\
(-5.81)\end{array}$ & $\begin{array}{c}-0.0006^{* * * *} \\
(-6.56)\end{array}$ & $\begin{array}{c}-0.0005^{* * *} \\
(-6.35)\end{array}$ \\
\hline Constant & $\begin{array}{c}0.0120^{*} \\
(1.84)\end{array}$ & $\begin{array}{c}0.0212^{* * * *} \\
(3.17)\end{array}$ & $\begin{array}{c}0.0120^{*} \\
(1.81)\end{array}$ & $\begin{array}{c}0.0210^{* * * *} \\
(3.09)\end{array}$ \\
\hline Observations & 803535 & 803534 & 771276 & 771276 \\
\hline Average $\mathrm{R}^{2}$ & 0.06 & 0.06 & 0.06 & 0.07 \\
\hline Fama-MacBeth & Yes & Yes & Yes & Yes \\
\hline
\end{tabular}




\section{Appendix 1: Variable Definitions}

This table displays the variable definitions for all variables used in the regressions. All variables are company variables on a weekly basis, unless explicitly stated differently. Company and date indices are omitted for better readability. All continuous variables are winsorized at the $1 \%$ threshold.

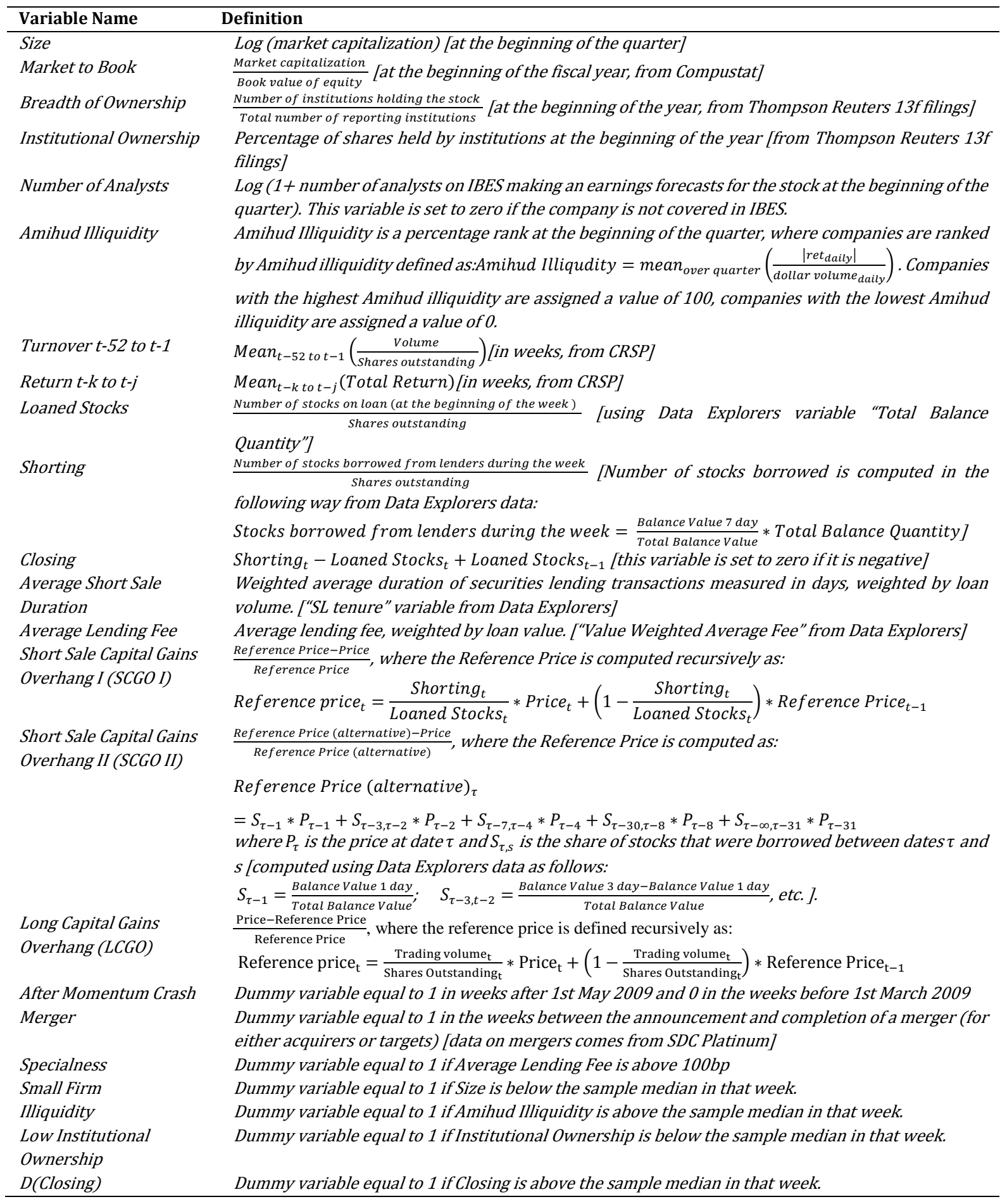

